\title{
POINT FOUR: A RE-EXAMINATION OF ENDS AND MEANS
}

$\mathrm{O}_{N}$ January 20,1949, without warning or fanfare, a new moral and financial commitment was thrust upon the American people. President Truman pledged the United States to promote the economic development of the underdeveloped areas of the world. ${ }^{1}$ American foreign policy, responding to low living standards and growing demands for a better way of life, took on its now famous "Fourth Point." 2

1. "Foutrth, we must embark on a bold new program for making the benefits of our scientific advances and industrial progress available for the improvement and growth of underdeveloped areas ...

"[W]e should make available to peace-loving peoples the benefits of our store of technical knowledge . . . and . . . foster capital investment in areas necding development.

"Our aim should be to help the free peoples of the world, through their own efforts, to produce more food, more clothing, more materials for housing, and more mechanical power to lighten their burdens." Inaugural Address of the President, N.Y. Times, Jan. 21,1949 , p. 4 , col. 3.

2. "More than half the people of the world are living in conditions approaching misery. Their food is inadequate. They are victims of disease. Their economic life is primitive and stagnant. Their poverty is a handican and a threat both to them and to more prosperous areas." Inaugural Address, stpra note 1 . The President's statements are born out by statistics. Some 28 countries with two-thirds of the world's population are classified as underdeveloped (annual average per capita income under $\$ 100$ ). DEpartarent of State, Point Four 103-4 (Rev. ed. Jan. 1950). These countries are located primarily in Central and South America, Africa, and the Near and Middle East. Id. at 15. The following table suggests the gap between the developed (annual average per capita income over $\$ 200$ ) and the underdeveloped countries:

$\begin{array}{cc}\begin{array}{c}\text { Indicators of } \\ \text { Well-Developed } \\ \text { Countries } \\ 461\end{array} & \begin{array}{c}\text { Declopment } \\ \text { Underdereloped } \\ \text { Countrics }\end{array} \\ 3040 & 41 \\ 26.6 & 2150 \\ 111 & 12 \\ 1.06 & 1 \\ 63 & .17 \\ 5 & 30 \\ & 78\end{array}$

Per Capita Income (U.S. Dollars per annum)

Food Consumption (Calories per day per capita)

Energy Consumed (Hp. hours per capita per day)

Motor Vehicle Registration (Per thousand popuation)

Physicians (Per thousand population)

Life Expectancy (at birth)

Percentage of Illiteracy (Age 10 and over)

* These official figures are assembled in Piquet, Point Four and World Production, 268 ANNALS 152-3 (1950).

The great disparity in living standards has achieved new significance with the rapid advance of communication. The backward peoples are becoming aware-and dissatisfied. Their "revolt against hunger and poverty" has been called "as great a threat to civilization as the atomic bomb." Sir John Boyd Orr, former FAO Director, in the N.Y. HeraldTribune, May 1, 1950, p. 17, col. 3. Fortune has summed up: "Comparative living standards, once a statistical exercise, are now political dynamite" Point IV, Fortune, February 1950, p. 91. Secretary of State Acheson has served varning on Congress: "Increas- 
Point Four began as a mere statement of purpose, but it is slowly being translated into a concrete program. Congress has authorized a small appropriation to provide the backward areas with technical assistance. ${ }^{3}$ This assistance will enable underdeveloped countries to make more effective use of available labor, capital, and natural resources. ${ }^{4}$ But development can not take place without actual capital investment. ${ }^{6}$ Although much of this

ing numbers of people no longer accept poverty as an inevitable fact of life. . . These are the facts we must face. What do they mean to our national security? To the peace and well-being and freedom of the American people-in short, to the fundamental aims of our foreign policy?" Statement of Secretary Acheson on Point Four beforc the Senate Foreign Relations Committee, March 30, 1950. N.Y. Times, March 31, 1950, p. 4, col. 2.

3. A total of $\$ 35$ million was authorized for technical assistance during the next fiscal year. See N.Y. Times, May 26, 1950, p. 1, col. 8. \$45 million had been requested by the Administration. $\$ 10$ million of the authorization will go to United States technical aid programs already existing. Aid underway to underdeveloped areas through the European Recovery Program will continue separately. See 96 Cong. Rec. 7811, 7829-30 (May 25, 1950) and Departanent of State, op. cit. supra note 2, at 79-80.

The Point Four bill, originally H.R. 7346 (Act for International Development), now Title IV of H.R. 7797 (Foreign Economic Assistance Act of 1950), gives the President broad powers to use appropriated funds for bilateral assistance programs or for contributions to multilateral programs conducted by the United Nations. See Secs. 4 and 5 of H.R. 7346 ; Secs. 404 and 405 of H.R. 7797.

From $\$ 10$ to $\$ 12.5$ million of Point Four funds have been pledged to the U.N., conditioned on the size of contributions from other countries. See N.Y. Times, Junc 13, 1950, p. 1, col. 2-3. The U.N. technical assistance program, given impetus by the President's Inaugural Address, was formulated by the Econogmic and Social Council. It was approved unanimously by the General Assembly on November 16, 1949. The program calls for $\$ 676,000$ for the fiscal year beginning January 1,1950 , to be financed from the U.N.'s regular budget; and for an indefinite amount, estimated at between $\$ 15$ to $\$ 25$ million, to be financed by voluntary contributions from member governments. See Wilcox, The United Nations Program for Technical Assistance, 268 Annals 45 (1950); TeClnical Assistance for Economic Development (International Conciliation No. 457, Jan. 1950).

4. Technical aid is a prerequisite to economic development. Usually it is in the form of technical experts and information, and training for local personncl. See Economic \& Social Councit, Technical Assistance for Economite Development, U.N. Doc. E/1576 (Dec. 28, 1949). Technical assistance operates in such fields as health, education and agriculture; transportation, communication and industry; public administration, finance and social services. See DEPARTMENT of STATE, op. cit. supra note 2, at 21-33. For some dramatic results from past technical aid, see Statement of Secretary Acheson, supra note 2, col. 4.

5. The lack of capital in backward areas is as great an obstacle to development as primitive techniques. See, e.g., Economic \& Social Council, Economic Development of the Underdeveloped Countries, U.N. Doc. E/1333, App. II, p. 2 (June 7, 1949). (Memorandum of the International Bank). Technical aid alone cannot yield substantial results: "What ... is the use of bringing expert medical advice to countries which have no ... adequate hospital facilities? ... [W] [Wat is the use of having the most up-to-date advice in the field of mining if there are no adequate means of communication between the mines and the cities and harbors?" Heilperin, Private Means of Imblementing Point Four, 268 ANNaLs 55-6 (1950). The futility of depending on technical aid unsupplemented by capital investment was seized upon to good advantage by opponents of Point 
investment can and must be supplied locally, economically backward countries must receive additional capital from abroad if they are to develop without severe hardships. ${ }^{6}$ Since it is the world's greatest source of investment capital, the essential task of backing technical aid with productive equipment falls inevitably to the United States.

Under current plans, capital investment for economic development is to be financed primarily with private rather than public funds. ${ }^{7}$ In this respect, Point Four differs markedly from other programs of foreign aid. The emphasis on private financing stems from the desire to reduce as much as possible the tax burden on the American people. It stems also from the traditional preference for private initiative in achieving policy objectives. Since the war, however, private investment in foreign countries has been

Four: "In other words, the Senator's (Connally) method of encouraging peace in the world is to send to the poor people he is talking about our technicians, our doctors, and our consultants, and then do what? ... We are going to say to them, 'Here is the prescription, you poor devil. Now go to your own drug store and get yourself cured." Sen. Millikin in the Senate's Point Four debate, 96 Conc. Rec. 7811, 7819 (Mfay 25, 1950).

6. The ability of the underdeveloped countries to finance their own development is limited. Domestic savings are small, and what savings take place are poorly utilized. In the absence of foreign financial aid, these countries must achicve "forced saving" through inflation, taxation, or direct controls on consumption. See Ecosxossic DEvelopMIENT OF UNDERDEVELOPED COUNTRIES, supra note 5, at 6-21 (Report of the SecretaryGeneral). Foreign investment makes possible the development of the resources and industries of a country without tremendous sacrifices by its people. "Totalitarian governments have frequently expanded the production of their countries greatly, with almost no assistance from foreign capital, but only on the basis of unnecessary suffering by their citizenry. In other words, goods for export to secure foreign cxchange and capital goods that could have been purchased with foreign capital were produced instead of goods for domestic consumption. Only totalitarian governments could force such privations on their peoples..." Reeves and Dickens, Prizate Forcign Inz'estments: $A$ Mcans of World Economic Development, 64 PoL. ScI. Q. 211, 219 (1949).

The world's total investment needs (outside of North America) have been estimated at $\$ 43$ billion a year for $1950-4$, of which $\$ 8.5$ billion must be provided by foreign investment. These estimates are based on current development plans. Some $\$ 17$ billion a year is required by the underdeveloped countries. $\$ 4$ billion of this amount must be supplied from foreign investment. The percentage of financing that must be done by forcign funds increases directly with the lack of development in the underdeveloped areas: Latin America-27\%; Africa-43\%; Near East-47\%; Far East-53\%. Eco:ousrc \& SocunL CouncI, sipra note 5, App. I, pp. 12-13 (Report of the Food and Agriculture Organization).

7. "We put primary emphasis ... on the need for stimulating an expansion of private investment. .. ." Statement of Secretary Acheson, sipra note 2, col. 3.

No appropriations have been made for public investment in the backward areas. The possibility of future appropriations, however, has not been entirely precluded. As finally passed by Congress, Point Four provides for "utilization of the resources of the United States, private and public." (Emphasis added.) See H.R. 7346, See 3(b) and H.R. 7797, Sec. 403(b), quoted 96 Cong. Rec. 7811, 7825 (1Fay 25, 1950). Nevertheless, with respect to projects for which capital is requested, U.S. government agencies are to talie into consideration "whether private capital is available either in the recipient country or elsewhere upon reasonable terms and in sufficient amounts to finance such projects." Ibid. 
small in amount and limited both as to area and industry. Unless this situation is corrected, present plans for foreign development are unlikely to produce significant results.

A number of incentives have been proposed to stimulate the flow of private investment abroad. To be successful, these incentives must do more than increase the general level of private investment. They must promote investment which is consistent with the specific objectives of foreign development. If they prove inadequate to this task-and if Point Four is taken seriously as a national objective - an alternative form of public investment must be devised. Properly conceived, therefore, the problem of Point Four is that of finding the most effective combination of private and government action. Whatever combination is finally chosen, it is likely to involve new institutions and new legal doctrines. The success of Point Four depends on the successful solution of these joint questions of law and policy.

\section{Why A PoInt Four Program?}

There can be no agreement on how best to implement Point Four until there is some measure of agreement on the precise goals that the program is meant to achieve. ${ }^{9}$ Characterizations of Point Four's objectives differ

8. United States private investment for the four post-war years 1946-9 totalled only $\$ 2.5$ billion or one-tenth of the $\$ 25$ billion in government loans and grants made available during this period. Council of Economic Advisers, The Economic Report of tur: President, Tables C-35 and C-37 (1950). Public funds- $3 / 4$ of them from the United States and Canada-have accounted for over $90 \%$ of total foreign investment since the war. Economic \& Socral Council, supra note 5, App. I, p. 2 (Report of the Food and Agriculture Organization). Over two-thirds of direct investments in facilities overseas during 1945-8 were in petroleum. A large portion of these were in Latin America and the Middle East. Rosenthal, Where Is the Money Coming Fron? 36-7 (Public Affairs Institute, Bold New Program Series, No. 8, 1950). Private investment declined from $\$ 1$ billion in 1948 to $\$ 374$ million in 1949, due largely to cutbacks in petroleum investment. Council of Economic Advisors, The Economic Report of the Puesident, Table C-35 (1950) ; Business Week, Feb. 25, 1950, p. 129.

An increase in private investment under Point Four will have to be achicved by increasing direct investments rather than investments in foreign securities. Public confidence in foreign issues has been impaired by a history of widespread defaults. Furthermore, portfolio investment does not represent the best way to achieve development of the backward areas. Direct operation of enterprises abroad assures control over the use of investment funds; brings technical assistance with investment; and avoids inflexible service charges on the exchange resources of underdeveloped countries. See generally, LEWIS, THE UNITED States and Foreign Investament Problems 141-6 (1948); Coudert \& Lans, Dircel Foreign Investment in Underdeveloped Countries: Some Practical Problems, 11 Law \& ConteMr. Prob. 741, 742-5 (1946).

9. Of course, some profess to see no purpose in developing the backward areas at all: "It is of the utmost importance not to accept the principle of Point Four. . . We cannot give our cake away and eat it too." HazLitT, Illusions of Point Four 44-5 (Foundation for Economic Education 1950). "Once you accept the premise that it is the duty of the United States to provide for economically-backward peoples, everywherc, there is literally no place to stop." Wall Street Journal, Sept. 29, 1949, p. 6, col. 1. In the United States Senate, a move to kill all Point Four appropriations failed by the narrow 
strikingly in emphasis. Some see the program primarily as a vehicle for the spread of free enterprise. ${ }^{10}$ Others see it primarily as a weapon against the Soviet Union. II Official statements, on the other hand, emphasize objectives that are far broader in scope.

Although the fact is not always articulated, Point Four seems essentially to be grounded in humanitarianism. ${ }^{12}$ Its first objective is to promote higher living standards in the underdeveloped areas. But greater wealth is not desired for its own sake alone. It is supposed to provide the material environment necessary for greater freedom, opportunity, and personal dignity. ${ }^{13}$

margin of one vote. N.Y. Times, MLay 6, 1950, p. 1, col. 8. Senator Robert A. Taft, R, Ohio, protested that Point Four had not been justified by any "intelligent presentation" and was "just another method of spreading government money around the world." Id. at p. 2 , col. 7. Senatorial opposition to the program erupted in a full-fiedged debate on Miay 23-5, 1950. Senators Millikin, Wherry and Taft challenged the basic assumptions behind foreign development. See 96 CoNG. REc. 7602 et seq., especially 7812, 7826-8, 7838-9 (May 23, 1950). Sen. Millikin called Point Four a "damnable provision" and evoked a demonstration from the galleries with a ringing peroration: "We will be so involved in it that we will never be able to terminate it. We will have such big payrolls, so many vested interests, so many clerks, so many lawyers, so many commissions, so many joint commissions, that there will be no way in God's world of getting rid of it." Id. at 7818-9.

10. "[C]ountries which desire our help would be more or less required to accept the free-enterprise system of operations." Hendershot, Bacluturd Nalions, N.Y. World Telegram-Sun, Feb. 29, 1950. "American private enterprise must form the cornerstone of the program for economic advancement in the underdeveloped areas of the vorld." Chantrer of Coarderce of the U.S., The Point Four Prograss-A Busizess View-

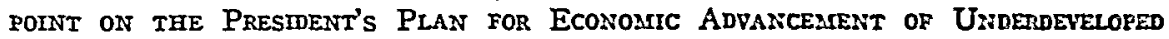
AREAs 8 (Oct. 1949). For the approach of business groups toward Point Four, see NAtional Foreign Trade Council, Private Enterprise and the Porni four Pecgrass (May, 1949) ; U.S. Council of tae International Canzrger of Cosaresce, Initelligent International Investaient (April 6, 1949); National Associationi of Mlasivfacturers, The Bold New Plan-A Prograzr for Underdeyeloped Areas (alay, 1949).

11. "Willingness to cooperate with the United States" in a "struggle against Communism and other forms of statism" were conditions to be met by the underdeveloped countries before they could receive Point Four aid under H.R. 6026, a bill introduced August 17, 1949 by Congressman Christian Herter. H.R. 6026, §2. The bill was later withdrawn to make way for the compromise bill, H.R. 7346, stpra note 3 .

12. "The United States and other free nations of the world have a common concern for the material progress of [backward] people . . . as a humanitarian end in itself. . .." DEPARTAIENT OF STATE, supra note 2 , at 2.

13. "[T]he President's idea is a way to improve [the] material welfare [of the backward peoples] and at the same time [help them] live as free men, retain their personal dignity and independence, and develop to the full extent of their individual capacities. They are offered a way of life that leads not only to freedom from want but also the most priceless freedom-the right to be let alone." Address by Secretary Acheson, Oct. 29, 1949, reported in 21 Dep'T of STATE BULl. 719. Economic development by foreign investment has not always led to these results. The reason is not only to be found in the errors of Western imperialism. It is partly due to the fact that the spread of Western production techniques does not automatically bring about greater happiness and contentment. See Bowles, Point Four and Improved Standards of Living, 268 Arrsuls 140 (1950). 
The various benefits to be derived by backward areas are also calculated to yield substantial rewards for the United States. ${ }^{14}$ An important aspect of - Point Four is its place in a total program for American security. ${ }^{16}$ For the present, underdeveloped areas in the Soviet orbit appear closed to Point Four development. ${ }^{16}$ But most of the peoples of the Middle East, Asia, Africa and South America remain uncommitted in the world's great idcological and political struggle. A program which assured rising living standards in these areas would enable the backward peoples to satisfy their various aspirations through free institutions and by peaceful means. In this way, it could provide an effective weapon against political instability, social unrest, and the spread of totalitarianism. ${ }^{17}$ In the long run, it could reduce the threat of war and contribute to the achievement of permanent peace through the United Nations. ${ }^{18}$

14. "Our policy ... is based on the assumption that . . . our own welfare is closely related to that of other peoples." Statement of Secretary Acheson, supro note 2, col. 3. This familiar assumption is supported at greater length in Hayes, Point Four in Unilcd States Forcign Policy, 268 AnNals 27 (1950).

15. "In a very real sense, [Point Four] is a security measure." Statement of Secretary Acheson, supra note 2, col. 2.

16. The Soviet Union has attacked Point Four as an imperialistic attempt to penctrate the underdeveloped areas, and has even offered the prospect of Soviet assistance to countries rejecting United States aid. Yakobson, Soviet Concepts of Point Four, 268 ANNals 129-131 (1950). Although the Soviet Union voted in favor of the General Assembly resolution for the U.N. technical aid program, it warned that there remained "different concepts" as to the nature of technical aid and "it remains to be seen which triumphs." Id. at 131 n.1. In contrast with the Marshall Plan, aid under Point Four is not now being offered to members of the Soviet bloc. See, e.g., the list of underdevcloped areas in Department of State, supra note 2, at 15. Even if aid were offered to underdeveloped areas under Soviet control, acceptance would be difficult. The "cold war" has already kept most of the members of the Eastern bloc out of U.N. economic institutions, and by December 1949, United States trade with the Soviet Union and its European allies (Czechoslovakia, Poland, etc.) had dropped to one percent of total U.S. trade. Compiled from figures in Monthly Survey of Foreign Commerce of U.S., December, 1949 (U.S. Dep't Commerce, Bureau of Census, March, 1950). The Communist victory in China may have cut off another underdeveloped area from possible Point Four operation.

17. "[The underdeveloped areas] must create a sound economic base for the democratic aspirations of their citizens. Without such an economic base, they will be unable to meet the expectations which the modern world has aroused in their peoples. If they are frustrated and disappointed, they may turn to false doctrines which hold that the way of progress lies through tyranny." Point Four message of the President to Congress, June 24, 1949, Departanent of State, supra note 2, at 97. But see The Economist, Oct. 15, 1949, p. 824: "[T] $T$ he contributor to Point Four schemes would be mistaken in thinking that, even where the spending of his money is successfully administered, it would serve as an immediate antidote to communism. Paradoxically, any change for the better in the Asiatic peasant's miserable circumstances seems to wake him out of his fatalistic lethargy only to render him receptive to communism whisperings that he ought to be getting more."

18. The U.N. might be strengthened if Point Four created an environment more favorable than the present one for the peaceful settlement of international disputes. To the extent that the U.N. had responsibility for carrying out the program, its authority and prestige might also be enhanced. See DEPARTMENT OF STATE, supra note 2, at $13,14$. 
The expected benefits of Point Four are economic as well as political. ${ }^{10}$ Present levels of employment and income in the United States are closely related to the current export surplus and the government aid programs that make it possible. ${ }^{20}$ If these programs end without new foreign investment to replace them, drastic adjustments will have to be made by American industry and agriculture. ${ }^{21}$ European recovery, not to mention the recovery of the rest of the world, will be seriously jeopardized."2 A program of increased investment in the backward areas would avoid these results. The steady flow of dollars abroad would be continued. Although the European nations would no longer be the immediate recipients, they would benefit indirectly. By providing them with both new markets and new sources

In the view of some, "the success of the Point Four program may be a major factor in determining whether or not we have to live in a garrison state." Salant, The Domestic Effects of Capital Export Under the Point Four Progan, 40 Axr. Eco:r. Rev. 495, 503 (1950). Note, however, the interesting comment of Rose, Necds and Resourecs of the Brave Nero World, 268 AnNals 9, 12 (1950): "Almost without discussion, it is assumed that ... development would result in better-nourished, better-adjusted, more stable and happier populations and nations; hence that the welfare of mankind vould be advanced and the world would be more peaceful. We need note only that the great wars of recent times have not been fought by or in the underdeveloped areas; only those with comparatively well developed agriculture and industry have found it necessary, or have been able, to engage in destructive modern war in a major way."

19. See, e.g., Mressage of the President to Congress, supra note 17, at 9S: "To increase the output and the national income of the less developed regions is to increase our own economic stability."

20. U.S. exports totalled $\$ 12.0$ billion during 1949 , imports $\$ 6.6$ billion, leaving a net export surplus of $\$ 5.4$ billion. Montely Survey of Foresgn Counareres of U.S., December 1949 (U.S. Dep't Commerce, Bureau of Census, March, 1950). U.S. government aid during 1949 totalled $\$ 5.2$ billion in grants, $\$ 0.5$ billion in long-term loans. Cousien. of Econosric AdVISORs, supra note 8, Table C-37. By February, 1950, monthly exports were $\$ 770$ million, imports $\$ 599$ million, compared with $\$ 1,044$ million and $\$ 567$ million, respectively, in February, 1949. Survey of CuRrent Business 2-3 (U.S. Dep't Commerce, April 21, 1950). On this basis the export surplus during 1950 is running at an annual rate of approximately $\$ 2$ billion.

21. "If the heavy burden of adjustment is not to be concentrated over a short period of time on a limited segment of American economic life, there will have to be continued loans and (or) aid long after 1952." Harris, Forcign Aid and the Domestic Economy, 23 Acad. PoL. Scr. Proc. 382, 395 (1950). Without additional financial aid, forcign countries, and Europe in particular, would have to reduce imports of American goods, increase exports to the U.S., or displace U.S. exports in third countries. This "may very vell bankrupt many American firms and seriously damage the status of industries dependent upon foreign markets for $10 \%$ or more of their markets-for example, fruits, dairy products, bread grains, tobacco, typewriters, machine tools, cinema products, testiles." Id. at 386-7. See also Salant, supra note 18, at 499.

22. See e.g., the report of U.N. economists that "no remedy is yet in sight" for the imbalance in world trade and the heavy dependence of Western Europe on American dollar aid. N.Y. Herald-Tribune, Feb. 17, 1950, p. 9, col. 1. Further aid is necessary to avert serious economic and political consequences. See Address of President Truman at the University of Missouri, June 9, 1950, reported in N.Y. Times, June 10, 1950, p. 1, col. 8 and p. 2, cols. 2-7. 
of raw materials, Point Four would help balance their trade with the United States. ${ }^{23}$ Finally, the program would contribute to the prosperity of the whole Western world by helping to maintain high levels of American income and employment. ${ }^{24}$

Point Four cannot be justified, however, as a permanent means of perpetuating the American export surplus. A surplus of exports over imports can only be maintained by annual increases in foreign investment. ${ }^{20}$ This so-called lending process would mean, as it has in the past, an annual gift of the national product to foreign countries. ${ }^{26}$ Such a policy maintains employment at the expense of real income. Furthermore, the same gift to underprivileged in the United States would provide an equivalent if not a superior stimulus to domestic employment. ${ }^{27}$

23. Development of the resources of the backward areas may enable European industry to obtain raw materials more cheaply; Europe's dependence on dollar sources for these materials may also be reduced. In addition, dollars invested in the underdeveloped countries will partly make their way to European nations, further increasing Europe's dollar supplies. See Salant, supra note 18, at 500 . These consequences explain the statement of ECA Administrator Paul Hoffman: "I think one of the greatest hopes for a self-supporting Europe within a reasonably short period of time has got to come through the development of these overseas territories. ..." Hearings before Commillec on Foreign Affairs on H.R. 5615, 6026, 6834, 6835, 7346, 81st Cong., 1st and 2nd Scss. 417 (1950).

24. The relation between prosperity and a large export surplus is sometimes explained in terms of the need of the American economy for a high volume of capital investment. Pent-up demand has kept the proportion of American resources devoted to domestic investment somewhat higher than can be continuously maintained. Domestic business expenditures on new plant and equipment dropped in 1949 and are expected to drop still further in 1950. See Council of Economic Advisors, op. cit. sipra note 8, Table C-17. See also Business Week, Jan. 21, 1950, p. 73. Since prospects for a substantial expansion of domestic investment or domestic consumption do not appear favorable, forcign investment is suggested as a substitute. See Salant, supra note 18 , passim.

The maintenance of American prosperity is essential for other countries becatuse of the intimate relation between U.S. national income and U.S. imports of foreign goods. An American depression would soon be felt in the industry and agriculture of all the major Western nations. See The U.S. IN THE World Economy 14-16 (U.S. Dep't Commerce 1945).

25. New loans must not only cover the gap in trade but must also make possible the rcpayment with interest of past loans. Thus the gross outflow of new capital would have to increase at a percentage rate equal to average realized interest and dividend payments. Salant, supra note 18, at 504-6.

26. Seymour Harris estimates that the U.S. has exported $\$ 100$ billion worth of goods since 1914 , received no more than $\$ 20$ billion in return. Harris supra note 21 , at 384 . Much of the gap is the result of two world wars. Much is also the result of the international "confidence trick" by which loans are made which cannot be repaid, necessitating further loans, and finally default. See Carr, Condrrions of Peace 269 (1942).

27. The United States, as well as the rest of the world, has "underdeveloped areas." Political considerations aside, is a Point Four project in Tennessec less desirable than one in the Belgian Congo? Not only does the former preserve the direct results of development for the American people; it may have a greater total effect on domestic employment and income: "[U]nless one is prepared to disregard the rate of change to 
The rational alternative to reducing exports or maintaining indefinitely the present export gap is to increase imports and balance American trade at a permanently high level. To obtain repayment of past debts, the United States must eventually adjust to the role of a net importer. ${ }^{23}$ This adjustment will enable the American people to share more fully in the gains from trade. If vigorous domestic full employment policies are pursued, it need be no threat to economic stability. ${ }^{29}$

Point Four can provide the time and the means to make this change. A program of investment in the backward areas could greatly ease the lack of foreign productive facilities which is the principal reason for the dollar shortage. Industrialization of the backward areas, bringing with it a higher level of world trade, ${ }^{30}$ would help maintain American exports at their present

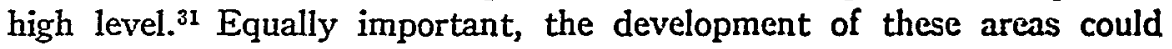
provide new and valuable American imports. By absorbing more raw materials from abroad, the United States could relieve dwindling domestic resources and accelerate strategic stockpiling. ${ }^{32}$ Gradually, the trade of the United States and the rest of the world could be brought into balance. A greater amount of free international trade might be facilitated. In this way the gains from trade would create a climate more favorable to traditional American economic institutions. ${ }^{33}$

a given stimulus or is indifferent to the amount of spending necessary to achieve a given result, foreign investment and home investment are not identical and cannot be so regarded." Buchanan, INternational Investarent and Dosicstic Welfake 149 (1945). Furthermore, \$2-3 bilion spent in foreign investment annually "cannot be expected to produce more than a minor stimulus to American national income" Id. at 142. But see Salant, supra note 18, at 497: "The effects of net foreign investment on domestic employment are, in general, as great per dollar as those of domestic expenditures."

28. A creditor nation can only be paid back for its surplus of exports in the past by developing a surplus of imports in the future. From an economic point of view, this is not only inevitable; it is desirable. Imports, for which nothing is exported in return, give us "more goods for the same.amount of work and thereby provide us with the opportunity to attain a higher standard of living. ..." Salant, supra note 18, at 510. See also HoOver, INTERNATIONAL TRADE AND DoMrestic EMrPLoyarent 20-4 (1945).

29. See, Hoover, op. cit. supra note 28, at 14 ; Salant, supra note 18 , at 509-10.

30. Under normal conditions, international trade varies directly with industrialization. See Industrialization and Foreign Trade (League of Nations) 14-29, 118 (1945). The link between industrialization and trade is cut, of course, in the presence of non-economic factors: wars, trade controls, and the deliberate promotion of autarchy. To a certain extent, also, very highly developed countries such as the United States tend to spend a greater proportion of their income on services, which usually must be supplied locally rather than through foreign trade.

31. A steadily expanding demand in the underdeveloped countries could ofiset slackening demand for American manufactures caused by satisfaction of Europe's wartime capital losses or competition by European industry in traditional American markets.

32. See Departasent of State, stipra note 2, at 12.

33. This result could come about in at least three ways: (1) The increased supply of dollars relative to the demand for dollars would make foreign exchange controls and other restrictive practices less necessary. (2) Investment aid to underdeveloped countries would enable these countries to develop their economies with less reliance on trade con- 


\section{Factors Restricting the Role of Private Investment in Carrying OUT Point Four}

Any method chosen to promote the objectives of Point Four will face formidable obstacles. These obstacles are particularly discouraging to private investment, which requires a minimum rate of return and is less able than public investment to ignore serious risks. They cast grave doubts on the ability of American business to participate in foreign development.

One of the most serious obstacles to private implementation of Point Four is the present world crisis. Countries within the Soviet bloc are closed for the moment to foreign investment. Countries that are outside, but peripheral to, the Soviet orbit are becoming poor investment risks. Even in countries removed from the centers of conflict, political instability and the possibility of violence on a global scale reduce the normal investment flow. ${ }^{34}$

In addition to international friction, government participation in economic life is itself a major obstacle to foreign investment. Some government controls, of course, may be of temporary duration. Due mainly to present disorders in the world economy, they may be alleviated by the continued flow of productive dollar investment. ${ }^{35}$ Other controls, however, seem permanently entrenched. In many countries, government allocation of labor, capital and material resources has become a standard and perhaps essential part of development planning. ${ }^{36}$ Effective development can seldom take

trols and fewer controls on domestic consumption. (3) The political and cconomic benefits of the program might reduce the need for government props to agricutlure or industry, and eventually the staggering burden of military expenditures. To suggest thit freer economies may be encouraged by Point Four, however, is very different from demanding acceptance of free enterprise as a condition of Point Four aid. See note 10 stlpra.

34. "Perhaps the greatest immediate obstacle to private foreign investment is the present conflict of ideologies between the East and the West. . . . Not only is there actual danger to the capital invested, but ... economic conditions tend to make operation of capital unprofitable and remission of profits, if earned, impossible. . . ." Recves and Dicl:ens, supra note 6, at 226-7. See also Economic and Social Council, supra note 5, App. IV (Extracts from Report of 3rd Sess. of Sub-Comm. on Ec. Devel.) 7.

35. See Black, The World Economy Since the War: Problems and Prospects, 26 VA. Q. Rev. 1, 18 (1950), and Viner, Trade Relations Between Free Market and Controlled Economes 87 (League of Nations 1943).

36. "[E]conomic development on the scale required in the underdeveloped countrics ... is not likely to be secured without a significant part being played by national governments. Modern technology requires capital and technical skills, which call for government aid in many cases and in some, even for government enterprise. Moreover, underdeveloped countries are usually confronted with a scarcity of currently available resources for economic development, necessitating their strict husbandry and regulated use, which in turn involves special action by their governments." Economic AND Social Council, supra note 5, App. IV (Extracts from the Report of the 3rd session of the Sub-Comm. on Ec. Devel.) 4 n.1 (quoting Report of Subcommission, 1st sess. E/CN.1/47 p. 14). For a detailed exposition of the need for government planning in the development of backward areas, see Bonne, The Economic Development of the Middle EAst (1945). For the predominant part that governments currently play in development of these areas, sce Hoskins, Point Four with Reference to the Middle East 268 Annals 85, 92-3 (1950). 
place without fiscal and monetary controls to check incipient inflation, or foreign exchange controls to insure that the dwindling supply of foreign currency is employed only for the most essential imports. ${ }^{37}$ Broad government planning is often required to control population pressure ${ }^{\text {ss }}$ and achieve essential social reforms. ${ }^{39}$ Finally, many countries-developed and undeveloped-are committed to some form of socialism. In these, private enterprise is faced with a steeply progressive tax structure. It may encounter sweeping price and wage controls and competition from government corporations. It may even be faced with outright exclusion from part or all of the economy.

The inhibiting effects of socialism and the threat of war are further aggravated by the rising tide of nationalism in the underdeveloped areas. Those peoples which have reached the stage of self-government have been most anxious to protect themselves against traditional forms of foreign imperialism. ${ }^{40}$ They have enacted restrictions designed to control or perhaps elim-

37. Inflation and balance of payments difficulties normally accompany development, especially in the early stages. Additional production of capital goods creates new money income without a proportionate increase in consumer goods. Development projects, requiring machinery and equipment from abroad, increase the demand for forcign exchange; and by diverting resources from export industries, they frequently reduce the supply. Higher domestic incomes and prices add to the demand for forcign capital goods an additional demand for cheaper foreign consumer goods or luxury items which could not be afforded previously. If development is to continue successfully, these tendencies must be controlled. See AdLer, The Underoeveloped Areas-Their Isdustnulizationi 19, 22-3 (Yale Institute of International Studies 1949).

38. Population pressure is one of the most serious problems in development. Unless development achieves a certain minimum rate, population increases (resulting from improved health conditions, for example) will outstrip the rate at which production of consumer goods is increased. If this occurs, development will bring a lower standard of living, not a higher one. See Econosnc \& Soctal Counch, supra note 5, App. I (Report of the FAO) 20. It is significant to note that gross output of the bachward countries has risen in recent years by every measure cxcept per capita. See Point Four, Fortune, Feb. 1950, p. 91. See also Valeo, Point Four Problens in the Far East, 268 Axisuls 104, 110 (1950).

39. Perhaps the most important example is the need for reforms in land holding. See the program of the U.S. Joint Commission on Rural Reconstruction in China, discussed in Hearings before Committee on Forcign Affairs on H.R. 5615, 6026, 6\$34, 6\$35, 7346, 81st Cong. 1st \& 2nd Sess. 353 et seq. (1950). "MFore and more on-the-spot students of Far Eastern Affairs are becoming convinced that further American aid in Asia will fail as an Anti-Communist measure, unless it is based squarely upon land reform. They do not decry the need for technical assistance, as envisaged in President Truman's Point IV program. They do say that such assistance will fail, as it failed in China, unless it is based on an improved peasant economy." Id. at 377. See also Peffer, Point One in A Policy For Asia, N.Y. Times Magazine Section, May 14, 1950, pp. C0-2.

40. This anxiety was reflected in the U.N. report, supra: "[T]he introduction of foreign capital should not be ... made in a manner or on conditions which are detrimental to the national interest and sovereignty of the underdeveloped countries nor should it be linked with any political or economic privileges for the capital exporting countries. ..." Economic \& Soctal Councri, supra note 5, App. IV (Report of 3d Sess. of Sub. Comm. on Ec. Devel.) 2. For past examples of political or economic interference 
inate outside influence in native life. ${ }^{41}$ Even the more mature countries have begun to enact legislation to preserve national pride and cultural independence against the spectre of American economic domination. ${ }^{42}$ Growing hostility and skepticism toward the motives of American business do not: augur well for the successful participation of private investment in foreign economic development. ${ }^{43}$

Non-self-governing countries give rise to peculiar problems of their own. In addition to native nationalism, private investment in the colonies must often contend with hostile policies from colonial governments. Colonial

in domestic affairs as a result of private investments, see Staley, WAR AND the Private INVESTOR (1935). Note the resentment against foreign capital in the early history of the United States. Id. at 390. Perhaps a suitable political climate for foreign investment in the underdeveloped countries will be achieved as "national inferiority complexes" aro corrected and "small nations can be confident that their rights will be fully respected in practice." Coudert \& Lans, Direct Foreign Investment in Undevcloped Countries: Some Practical Problems, 11 LAW \& Contens. Prob. 741, 759 (1946). A practical example of this occurred when investing powers gave up their extraterritorial privileges in China; that country promptly repealed legislation restricting the rights of foreigners to own property. Ibid. Note the phrase in the President's Inaugural address, supra note 1, col. 3: "The old imperialism-exploitation for foreign profit-has no place in our plans."

41. "[T] fundamental problem which now confronts foreign enterprise is that of adapting itself to the new economic nationalism of Latin America and the Near and Far Eastern Countries, exemplified by a wave of restrictive legislation, and, more important, by the general determination not to permit alien capital to maintain a dominant position in local life." Coudert \& Lans, supra note 40, at 752. For enumeration of the kinds of restrictions employed against foreign investment, see, Eden, Some Restrictions Abroad Affecting Corporations, 11 Law \& Contenip. Prob. 713 (1946); Bonsal \& Borges, Limilations Abroad on Enterprise and Property Acquisition, 11 LAW AND ContEMr. Prod. 720 (1946).

42. See, e.g., the French ban on importation of Coca-Cola, which had political and social as well as economic origins. N.Y. Times, March 2,1950, p. 18, col. 1. The action of the French National Assembly can best be comprehended by those who have seen firsthand the reaction to American business in Europe. "It seems that one of the sights of Venice these days is the Coca-Cola gondolas, navigating the Grand Canal with their huge yellow coolers amidships, dispensing pop to the Venetians in the shadow of the Palazzo Loredan. It would have delighted Mark Twain, no doubt. But the Venetians, apparently, believe the United States forced them to drink cokes as a condition of Marshall Plan aid. . . . Similar suspicions afflict England, Belgium, Holland, France, and Sweden. . .." Personal and Otherwise, Harpers, December, 1949, p. 8. See also Roberts, Uncle Sam's Friends Are Worried, id. at 47.

43. Yet many spokesmen for American business appear entirely unaware of the problem: "Foreign countries can be shown simply and convincingly that the record of American investment is almost immaculate." Address of N. A. Bogdan, Director of Finance, Ford International, before the 36th National Foreign Trade Convention, Nov. 1,1949 , p. 6. "Old fears of 'capitalistic exploitation' are pretty well exploded except in Marxist circles. ..." Point Foutr, Fortune, Feb. 1950, p. 96. Compare the observations in Condliffe, The Key to Economic Development, The Survey, April, 1949, p. 197-198: "The Corporations may disclaim any interest in the politics of their operations. They may be actuated solely by economic motives. But in the pursuit of profit-or merely of expansion-their operations have political consequences and those of many kinds. ... [T] hey arouse the envy and fears of other peoples." 
administration usually seeks to create political and economic conditions favorable to the governing country. American capital that spreads American influence, or causes competition for markets and raw materials, will not be regarded with favor. Investment may even meet frank opposition if it creates industries which drain rather than supplement available foreign exchange. Private investment will be blocked at every turn by the colonial government should it disrupt too far the political, economic, or social status quo. 44

Political obstacles are particularly serious in view of the poor prospects for profit offered by projects in backward areas. ${ }^{45}$ Private business can rarely operate profitably in a country with inadequate transport and power facilities, low levels of health, and a primitive agriculture. ${ }^{3}$ It may be additionally handicapped by inefficient or corrupt local officials, ${ }^{47}$ and by the absence of trained native personnel.48 Difficulties of this kind may be com-

44. For further analysis of the conflicting demands of the United States and the colonial governments, see Emerson, Point Four and Dependent Areas, 269 Awnass 112, 115 (1950) ; Dickinson, Point Four With Reference to Western Europe, id. at 122, 124-5. With regard to the economic problem, The Economist, Sept. 17, 1949, p. 603 notes: "[T] private American investor who has money to put into the colonics certainly has to face a formidable series of obstacles before he can do so. . . New enterprises will . . . have to pass the test of being dollar earning or dollar saving." With regard to the politieal problem, ECA Administrator Paul Hoffman has observed fear in colonial offices of a "new program of American imperialism to take over these colonies." Hearings bejore the Committee on Foreign Affairs on H.R. 5615, 6026, 6834, 6835, 7346, 81st Cong., 1st and 2nd Sess. 417 (1950).

45. Private capital is not normally invested abroad unless the returns from forcign investment are greater than those from domestic investment. "It must not be expected that corporations managed in the interests of public shareholders should have to consider investment under Point IV on humanitarian, political, social or military grounds." Bogdan, supra note 43, at 4. In 1948, American investments abroad yielded average returns of $15.6 \%$, compared to an average of $13.8 \%$ in corresponding domestic industries. Point Four, Fortune, Feb. 1950, p. 94, 182. Even this small differential is misleading: a large part of the returns on foreign investments were frozen abroad by exchange controls. In view of unfavorable political factors, few investors thought the slightly higher rate of return abroad compensated for the far greater risks involved. The comparatively high rate of return available on investment in the United States has therefore been called a basic "obstacle" to private participation in Point Four. Id. at 182.

46. "[P]rofitable opportunities for private investment in some underdeveloped areas must await the development of basic services in these countries. The lack of railroads and port facilities, for example, may make the utilization of certain resources impossible. Manufacturing industries may not be feasible, because there is an insufficient supply of electrical current." Departarent of State, Point Four 62 (Rev. ed. Jan. 1950). The deficiencies of underdeveloped countries in these fields are described in detail in id. at 21-3.

47. Private investment usually requires an independent judiciary and an efficient administrative system to handle its relations with the local government and the local population. See Sachs, Restoring the Economic-Cultural Bases of American Forcign Inestment, 23 ACAD. Poc. Scr. Proc. 408, 425 (1950). It is just possible, however, that business has sometimes been more helped than hindered by the villingness of local officials to trade special favor for cash. See, e.g., Staley, War and tae Parvate Investor 184 (1935).

48. Enterprises can not be run profitably abroad in the absence of experienced cm- 
pounded by attitudes among local business and labor that are fundamentally incompatible with the private enterprise philosophy. ${ }^{49}$ Basic development projects must begin to correct some of these handicaps before private investment will be attracted to the backward areas. Because they are longrun undertakings, yielding low and uncertain returns, such projects are seldom suitable for private financing. ${ }^{50}$

Even the establishment of minimum conditions of profitability does not insure the successful implementation of Point Four by private investment. The demands of the profit motive are not always compatible with the objectives of development. Commercial considerations have led private capital to concentrate heavily on investment in mineral resources and tropical agriculture. ${ }^{51}$ Development of this kind of ten provides the underdeveloped

ployees on the "intermediate" level-foremen, bookkeepers, field engineers, ctc. The process of transporting such personnel from the United States or training local personnel is often difficult and costly.

49. American business will have a difficult time enlisting the aid of local labor and capital in countries where the profit motive does not have as strong a hold as in the United States. People who prefer leisure to material rewards, for example, will react to higher wage rates by doing less, not more work. Note also, the psychology of the local capitalist: "In more than one Latin-American country that is reputedly 'short of capital,' the sums that have been spent in Paris in the last half century by wealthy natives would have endowed the country with a modern transportation system and a well-equipped industrial plant." Fetter, The Need for Postwar Foreign Lending, 33 Ax. Econ, Rev., 342, 343 (Supp. 1943).

50. The Economist, noting that $1 / 3$ of all investment in the British colonies during 1948 was devoted to transport facilities, commented: "Behind this . . . fact may well lic the biggest obstacle to any immediate flow of private dollar capital to the colonies. . . . The most urgent need of a great part of the colonial empire is capital for roads, railways and harbours, without which other development cannot proceed. ... Yet this is the type of investment on which returns are likely to be slow and unspectacular-and indecd which is regarded as being primarily, if not exclusively, the province of . . . governments rather than private enterprise." The Economist, Sept. 17, 1949, p. 603.

51. The fact that over two-thirds of direct investment since the war have been in the oil industry illustrates this point. See note 12 supra. For a survey of the range of agricultural and mineral products that have attracted foreign investment, see LEw1s, TuE United States and Foreign Investment Problems 86-107 (1948). The disproportionate emphasis on extractive industries can be explained by two factors: (1) Raw material development usually offers the quickest and greatest returns. For example, in 1948 American oil investments abroad yielded earnings of $25.6 \%$, compared to $17.6 \%$ in foreign manufacturing and $2.4 \%$ in public utilities. Point Four, Fortune, Feb. 1950, pp. 91, 182. (2) Foreign investors must concentrate on production for export to their home market. "The orientation of foreign capital investments must be determined... by the effect the investments are likely to have on the capacity of the receiving country to transfer dividends or debt service payments abroad. Investments in export industries or in public utilities that facilitate exports (such as railways from production centres to ports), clearly help raise the transfer capacity.... [I]nvestments in manufacturing for the domestic market would have no obvious effect on transfer capacity. . . I" Industrialization and Foreign Trade (League of Nations) 67 (1945). Erection of plants to process raw materials in the underdeveloped countries would be a way of increasing emphasis on local manufacturing investment, but many firms prefer to utilize existing plants in market 
countries with increased holdings of foreign exchange, and foreign corporations pay a part of their profits in the form of taxes or royalty payments. But these rewards are frequently enjoyed only by a small segment of the population. ${ }^{53}$ Natural resources are often steadily depleted without any permanent addition to the country's productive equipment. The fruits of development-higher real income and employment-are largely enjoyed elsewhere. ${ }^{54}$ As a result, commercially profitable development has frequently left the backward peoples impoverished and resentful. ${ }^{55}$

areas where there are less political and economic risks. See Coudert and Lans, supra note 40 , at $749-50$.

52. "[O]il and mining enterprises not only pay heavy royalties and taxes but also usually earn more foreign exchange than is required to service investment. ..." Point Four, Fortune, Feb. 1950, pp. 91, 96.

53. "Whatever gain has been obtained for the national economy (of the underdeveloped countries) was mainly received by the upper classes constituting a small minority of the population. . . . But the majority of the people continue to live as they have for centuries on a level of bare subsistence." George Hakim, counselor of the Legation of Lebanon at Symposium on Point Four held by the American Academy of Political and Social Science, quoted in N.Y. Herald-Tribune, April 15, 1950, p. 2, col. 4.

Thus an additional problem is raised: even if royalty or tax payments are substantial, how can their productive employment for the general welfare be insured? The ruling groups of many underdeveloped countries are either corrupt, indifferent to the needs of the masses, or at best simply devoid of the knowledge required to put the funds to effective use. Even where a private enterprise makes these problems its concern, it will be in a poor position to aid in their solution. Setting conditions on how funds should be used may mean losing a concession to a competitor who is somewhat less concerned with the public welfare; further, it will bring from vested local interests the traditional cry of "intervention" in internal affairs.

54. Three reasons have been advanced to support this theory: (1) Since interest and profits go to investors from abroad, the multiplier effects of investment are partially removed from the country where the investment takes place to the investing country. (2) The underdeveloped country is diverted into activities offering little scope for technical progress and does not therefore enjoy the advantages of modern technology. (3) The terms of trade are unfavorable to raw materials, and tend to deteriorate further. Thus capital goods producers in the investing countries sell their products at higher prices, get industrial raw materials at lower prices. Mreanwhile, the underdeveloped country suffers both ways. See Singer, The Distribution of Goins Between Investing and Borrowing Conntries, 40 Aar. Econ. Rev. 473, 477 et seq. (1950).

55. "[T] $T$ he preference shown by foreign capital for particular forms of investment ... as well as the tendency of foreign investors to insist on security of ownership and property, brought about a stagnation in other spheres of economic activity, which were more important to the welfare of the country as a whole. Thus, the process of industrialization was hampered, and the human and material capacities of the local population could not be fully developed." Bonne, The Econoaric Developarenst of tae Minobe EAST 97 (1945). A counter argument is frequently heard that forcign investment, though it may have deprived the backward areas of the full benefits of development, has at least left them better off than if there had been no investment, at all. This argument may have some validity, but it loses most of its significance at a time when underdeveloped countries are determined to develop themselves, and when the U.S. is seeking to promote development for particular humanitarian, political, and economic ends. Therefore, "the main requirement of underdeveloped countries would seem to be to provide for some method 
The tendency of private investment to concentrate in extractive industries is as serious an obstacle to Point Four as the factors which deter private investment entirely. Point Four can achieve its purposes only by diversified development. A certain amount of industrialization is needed to avoid the past misfortunes of one-crop agricultural economies and to bring eventual increases in living standards. The governments of the underdeveloped countries want more than diversification, however. They are demanding primary emphasis on heavy industry..$^{56}$ This is largely due to a desire for political and economic independence, as well as for greater military power. American conceptions of optimum foreign development may find these demands too extreme. ${ }^{57}$ No matter how these differences are compromised, however, the result promises to be very different from the kind of development generally engaged in by private investment.

The most confounding problems blocking the achievement of Point Four by private investment may be neither political nor economic, but social. It is far from certain that the private enterprise system which has yielded successful results in the United States will yield equivalent results in the underdeveloped countries. Grafting a highly industrialized, free-enterprise culture on a primitive society is a process charged with difficulty. ${ }^{63}$ If the native population is not helped to adjust to new physical environments and new social situations, economic development may leave them, and the rest of the world, worse off than before. American business must be prepared to supply that help. This is perhaps the most serious challenge that Point Four presents to private enterprise. It must provide- not simply dollarsbut a way of life. ${ }^{.9}$

of income absorption to ensure that the results of technical progress are retaincd. . . ." Singer, The Distribution of Gains Between Investing and Borrozving Cotmtrics, 40 As. ECON. REv. 473, 484 (1950).

56. The marked emphasis on industry may be seen in present development plans. See Economic \& Soctal CounciL, supra note 5, App. I (Report of FAO) 10, 12. Sco also ADLFR, op. cit. supra note 37, at 1 et seq.; id., App. IV (Report of the 3rd Session of the Sub-Comm. on Ec. Devel.) 1-2.

57. The Communist victory in China indicates the need to begin development by improving the lot of the peasant. Countries in the Far East urgently require improved methods of agriculture, better implements, rural roads, water supplies, and electrification. On the average, the governments of this area are planning to devote only $10 \%$ of investment to agriculture. See The Economist, Jan. 14, 1950, p. 58.

58. "People practising their accustomed modes of production, their ancient family and community life, and the forms of art and religion sanctioned by long usage, suddenly find all this disturbed and their lives unsettled by foreigners who introduce articles from abroad more cheaply than native craftsmen can make them, who ruin the livelihood of native transport workers by the competition of their iron horses, who put whole villages to work in factories and mines, and who desecrate the sacred places with tunnels and steel rails." Staley, op. cit. supra note 40, at 398. See also Bowles, supra note 13 , at 145.

59. "Indeed, if America could export its capitalistic mores, it would do more for Point IV than any amount of capital." Point Four, Fortune, Feb. 1950, pp. 91, 178. Apparently, some representatives of American business still have not grasped the fact that "capitalistic mores" do not always harmonize with an alien culture. Such short-sightedness plits the 


\section{Overcoming the ObStacles: the Relation \\ of InCENTIVES to the Goals Of the Progradr}

A number of proposals have been advanced to overcome the obstacles blocking private participation in Point Four. Each of the proposals provides an incentive to private investment in foreign countries. The ability to carry on significant programs of foreign development lies with the handful of corporations that currently accounts for the bulk of private investment abroad. ${ }^{60}$ To be successful, therefore, the incentives will have to induce these corporations to expand substantially their foreign operations. A general increase in the volume of foreign investment, however, is not all that is needed. Incentives will not be successful unless they direct investment to specific countries and to specific parts of their economies. Furthermore, an increase in investment should not be bought at the expense of other objectives of Point Four.

\section{The Tax Incentive}

The first type of incentive to increase the flow of private investment to the underdeveloped countries involves changes in the American tax structure. Proposed changes range from minor alterations in the treatment of certain types of income earned abroad to total tax exemption of all foreign income. These changes aim to increase the level of foreign investment by increasing prospective profit margins. In return for a small reduction in public revenues they are supposed to yield a substantial contribution to the Point Four program. ${ }^{61}$

United States citizens and corporations are currently taxed on income derived from foreign as well as from domestic sources." Since most countries tax income derived within their borders, income from American investment abroad is often subject to double taxation. However, a credit provision of the United States revenue code allows income taxes paid to foreign countries to be deducted from American taxes on the same income..$^{63}$

manifold social problems attendant upon economic development suggest that private enterprise may not be the best vehicle for adapting Point Four aid to the peculiar institutions and traditions of the backward areas.

60. Although two to three thousand American companies have foreign branches or subsidiaries, 10 of these have accounted for over 75 per cent of the net outflow of direct investment capital since the war. About twelve firms accounted for half of the income received on foreign direct investments in 1947. Departarent of State, supra note 2, at 61.

61. See generally Allan \& Coggan, Tax Planning for Foreign Trade, 3 TAx L. REv. 23 (1947); Carroll, Tax Induccnents to Forcign Trade, 11 Law \& Co:rt. Pron. 760 (1946) ; Share, Taxation of American Business Abroad, N.Y.U. Seventh Ann. Inst. on Fed. Tax. 812 (1949).

62. See note 61 supra.

63. Irt. Rev. Cone $\$ 131$. See Exhibit 6, The Tax Treatment of Foreign Income, 1 Hearings before Committee on Ways and Means on Revenue Revision of 1950, 81st Cong., $2 d$ Sess. 89 (1950). As an alternative, a taxpayer can deduct forcign taxes from his gross income under INT. REv. CODE 23 § (c) (I) (C). 
Two limitations combine to reduce the effectiveness of the tax credit. An "overall" limitation provides that the credit for all foreign income taxes shall not exceed that proportion of a taxpayer's liability which his net foreign income bears to his total income. ${ }^{64}$ This limitation was enacted to avoid the possibility that higher foreign income taxes would reduce an American taxpayer's liability on income derived in the United States. ${ }^{65}$ The "overall" limitation is supplemented by a similar "per country" limitation, under which high taxes paid to one foreign country cannot be used to increase the credit allowed for low taxes paid in another. ${ }^{66}$ With the enactment of the "per country" limitation, the "overall" limitation serves only to prevent a taxpayer from claiming a credit for taxes paid on income in one country which is offset by losses in another. ${ }^{67}$ The effect of this is to discourage firms who have already invested abroad from spreading out to other countries. One of a number of Treasury Department proposals ${ }^{68}$ made in connection with Point Four calls for the abolition of the "overall" limitation.

It should be noted that the credit provision has no value in avoiding double taxation when both the United States and a foreign country consider that they are the place of source for a given amount of income. Nor is the credit effective when the two countries employ different forms of income taxes and different concepts of taxable income. Bilateral tax conventions which iron out these inconsistencies are of some value to Amcrican business abroad. The United States now has tax treaties with Canada, Great Britain, Sweden, Denmark, France, and The Netherlands. Treaties with Belgium, New Zealand, Norway, Union of South Africa, and Ireland were presented to the Senate for ratification during the last session of Congress. Additional agreements with Colombin, Cuba, Mexico and Italy are currently under discussion. See id. at 90 . See also Seghers, Haw Amcricans Cau Best Do Business Abroad and Foreiguters Can Best Do Business Here, Amn. Inst. Fot. Tax. 926, 954 (1948) ; Share, supra note 61, at 823, The Effects of Taxation on Forcign Trade and Investment (United Nations) 34-55 (1950).

64. INT. Rev. Cone $\$ 131$ (b) (2).

65. "The income tax law allows a credit, dollar for dollar, against our tax for any income or profits taxes paid to any foreign country. . . . Where foreign income or profits taxes are imposed at rates higher than those carried by similar taxes in this country, this credit may wipe out part of our tax properly attributable to income derived from sources within the United States." Hearings, supra note 63, at 92, quoting House Report No. 350 on Revenue Bill of 1921,67 th Cong., 1st Sess.

66. INT. Rev. CODE $\$ 131$ (b) (1).

67. "With the adoption of the 'per country limitation,' the effectiveness of the 'over-all limitation' became limited to taxpayers that conduct business operations in more than one foreign country, and realize a loss in one country and a gain in another. Suppose, for example, that a taxpayer derives $\$ 1,000$ of income in Country $A$, and suffers a loss of $\$ 1,000$ in country $B$. On a net basis he has no income from foreign sources, and under the over-all limitation, he is not permitted any credit for the taxes paid to Country A." Hearings, supra note 63 , at 92.

68. These proposals were presented to Congress as part of the Administration's tax program. See the tax message of the President, Jan. 23, 1950, reprinted in N.Y. Times, Jan. 24, p. 14, col. 8. The proposals are summarized in Departurent of State, stlpra note 2 , at 69-71; statement by Secretary of the Treasury Snyder, Hcarings, stipra note 63, at 27-8.

69. "The over-all limitation in its present form .... impedes the establishment of additional enterprises by firms already engaged in business abroad. The risk of incurring a loss, is, of course, the major obstacle to new investment, and the over-all limitation 
A second Treasury proposal would provide more favorable tar treatment for foreign branches of domestic corporations. ${ }^{\circ}$ The income of a foreign branch has been taxed as soon as realized abroad on the theory that it is the income of the domestic corporation. By contrast, the income of a foreign subsidiary of a domestic corporation has not been taxed until returned to the United States. ${ }^{71}$ Because it makes possible loss-offset and greater freedom from foreign regulation, branch operation remains for many corporations the preferable form of foreign investment. ${ }^{72}$ Exemption of income held abroad by branches in the same manner as income held abroad by subsidiaries would enable corporations to combine advantages of branch operation with more favorable tax treatment. It would eliminate taxation on branch income that is accumulated, reinvested, or frozen abroad by exchange controls. ${ }^{73} \mathrm{By}$ encouraging productive reinvestment of profits earned abroad, ${ }^{74}$ it might provide a minor stimulus to foreign investment.

Another Treasury recommendation would alter slightly the tax treatment of income received from foreign subsidiaries.75 American citizens and corporations receiving dividends from subsidiaries have been entitled to a credit against United States taxes on these dividends, proportionate to that share of the subsidiary's total income that has been paid in foreign taxes. ${ }^{70}$ This credit, however, has been granted only to those holding a majority interest in a foreign subsidiary. It is proposed to extend the credit to minority stockholders, thus removing an arbitrary penalty on investors

tends to increase the burden entailed by that loss. Id. at 92. Abolition of the "per country" limitation was proposed instead by the Tax Committee of the National Foreign Trade Council. See International Trade Reporter, Survey \& Analysis of Current Developments, Feb. 17, 1950, p. 2. The NFTC proposal would provide a somewhat stronger incentive: American firms abroad would be able to average foreign tax rates, spreading high rates of certain countries over income from countries with lower rates. Ibid.

70. See Hearings, supra note 63 , at $90-91$.

71. Id. at 90 .

72. If branch operations resuit in a loss, that loss may be offset against income earned by the parent corporation in determining its income ta: A branch may also have a stronger claim to U.S. diplomatic protection than a subsidiary incorporated under foreign law, and may have generally greater freedom from foreign laws and restrictions. In 1947, approximately one-third of income from direct investments abroad was derived by branches of U.S. firms. See id. at 91 . For a summary of the relative merits of branch and subsidiary organization, see Allan \& Coggan, stepra note 61, at 37 et seg.

73. Under present law, if income kept abroad by exchange controls is considered available for use by the taxpayer, it is taxable. See Hearings, supra note 63, at 91; Mackey \& Smith, Private Capital Under the "Point Four" Program, $3 S$ Geo. L.J. 32. $56,57 \mathrm{n} .93$ (1949).

74. "[The change] would enable branches to obtain the benefit of tax incentives which some foreign countries offer for the reinvestment of earnings within their borders. At present a reduction in the foreign tax may be offset by a commensurate increase in the U.S. tax, and the inducement to reinvest is dissipated." Heariigs, supra note 63, at 91.

75. See Hearings, sipra note 63, at 91-2.

76. INT. REv. CODE $\S 131(f)$.

77. Ibid. 
who are restricted to minority holdings by foreign laws. ${ }^{78}$ Such a change is expected to foster a desirable trend toward joint enterprises among American investors or between Americans and investors of foreign countries. ${ }^{70}$

These and other comparatively minor tax changes ${ }^{80}$ can be justified on the grounds that they avoid specific instances where the tax burden on foreign income seems unduly harsh. Such marginal changes, however, will not greatly increase overall profit margins. They do not qualify as decisive stimulants to increase the flow abroad of private investment. ${ }^{81}$ Consequently, foreign trade interests have requested an extreme measure-total tax exemption for income derived in foreign countries. ${ }^{82}$

Complete exemption from American taxes of income earned abroad would enable private investment to benefit for the first time from foreign tax rates which are lower than American rates. This immediate benefit might lead to additional benefits, since foreign countries would now have an opportunity to offer tax incentives of their own. ${ }^{83}$ But a substantial tax exemption. is already available for corporations doing business in American possessions, ${ }^{84}$ in China, ${ }^{85}$ and in the Western Hemisphere. ${ }^{86}$ Exemption for

78. See note 123 infra.

79. Hearings, sitpra note 63, at 92.

80. Two other changes in the tax treatment of foreign income were proposed by the Administration: (1) Taxation of U.S. citizens permanently resident abroad. Exemption from Federal taxes has been enjoyed by American citizens only for the first full calendar year of bona fide residence abroad. INr. Rev. CODE $\$ 116(a)(1)$. It is proposed to broaden the exemption to include the first part-year of such residence, thus rcducing the tax burden on American personnel who participate in programs of technical assistanco or private investment in foreign countries. See Hearings, sutpra note 63, at 92-3. (2) Credit for foreign estate taxes. Transfers of property held abroad by U.S. citizens and residents are subject to the Federal estate tax. Although these transfers are frequently subject to foreign as well as U.S. taxes, foreign estate taxes have not been eligible for credit as have foreign income taxes. A final proposal, therefore, would extend the credit system to this field. Id. at 93-4.

81. Even if reinforced by government guarantees, see pages 1312-15 infra, "it's doubtful that [the proposed tax changes] will make a real break in the dam that is holding the flow of U.S. capital overseas down to a trickle." Business Week, Jan. 28, 1950, p. 74. See also note 88 infra.

82. See, e.g., National Foreign Trade Council, supra note 10, at 23.

83. Under present law, reduction of forcign taxes which are below U.S. rates only increases the taxpayer's liability to the U.S. government. Therefore, preferential trcatment by the U.S. is a prerequisite to preferential treatment by an underdeveloped country. Sce Economic and Social Council, sitpra note 5. (Report of the Sec.-Gen.) 27.

84. U.S. citizens or corporations that derive the bulk of their income from sources within a U.S. possession (Puerto Rico, Canal Zone, Guam, Samoa, Wake and Midway Islands) are exempt from the tax on such income provided the income is not received in the United States. See INT. Rev. Code $\$ 251$ (a) (b), Share, sulpra note 61, at 818.

85. Corporations organized under the China Trade Act of 1922 enjoy complete exemption from income and profits taxes, provided they distribute these tax savings in the form of special dividends during the year. See INT. REv. CODE \$262; Share, supra note 61.

86. A U.S. corporation that (1) does all its business in North, Central, or South 
operation in these areas has not achieved a significant increase in new investment. ${ }^{87}$ Apparently, tax incentives do not sufficiently neutralize the risks facing private investment abroad. 83

The only result that complete tax exemption seems likely to achieve is interference with the equitable distribution of the American tax burden. Exemption would provide a windfall for existing investment. The largest corporations would be the biggest gainers. They would also be in the best positions to reap rewards in the future. ${ }^{2}$ Thus total exemption of foreign earned income would not only force upon domestic income a disproportionate burden of revenue; it would foster concentration of wealth and economic power. ${ }^{90}$ These effects might be transmitted abroad if foreign countries were

America, the West Indies, or Newfoundland, (2) derives $95 \%$ of its gross income from sources outside the U.S. and (3) derives $90 \%$ of its gross income from the active conduct of trade or business, is exempt from the U.S. corporate surtax. See Ist. Rev. Cone $\$ 109$; Share, supra note 61 , at 819 . The surtax exemption usually is equivalent to a total tax exemption: "The combined effect of this special surtax exemption is to exempt many corporations who meet the requirements from all U.S. income and profits taxes. In most cases the present $24 \%$ normal tax is completely wiped out by the credit for taxes paid to the Western hemisphere countries." Share, ssspra note 61 , at 820 .

87. In 1940, for example, corporations that had bothered to qualify for the China Trade Act exemption accounted for only $4 \%$ of total direct investments in China. Share, supra note 61, at 819. "Past experience with tax exemption suggests that it is not likely to increase foreign investments appreciably. To date, the surtax exemption granted Western Hemisphere Trade Corporations appears to have provided a windfall to preexisting investments rather than to have stimulated new ones. The experience with the complete exemption of corporations operating in China and the Possessions is similar." Id. at 826.

88. "[I]nvestigations of the subject indicate that U.S. taxes have little weight in the corporate investors' appraisal of foreign investment opportunities." Departaseit of StATE, supra note 2, at 69 . "Non-tax factors have assumed an ever-increasing role so that a trader's or investor's decision is made before he even renches consideration of the tax factors involved." The Effects of Taxation on Foreign Trade and Investment (United Nations) \& (1950). Tax incentives are particularly ineffective because such a relatively small portion of foreign earned income is presently absorbed by U.S. taxes. Credits and exemptions already in effect reduce total revenue on foreign income to about one-quarter of what it would ordinarily be. Id. at $3 \mathrm{n} .2$. In 1939, net income from sources outside the U.S. totalled $\$ 378$ million. Only $\$ 14.5$ million was paid in taxes to the American government, $4 \%$ of the total.

To a certain extent, complete tax exemption might actually reduce forcign investment: "[I]f investors abroad viewed complete exemption as of temporary duration, they might utilize it to repatriate their accumulated earnings free of tax. . . " Share, supra note 61 , at 826.

89. Total tax exemptions are said to be "more valuable to the taxpayer, the greater his income, i.e., the less by definition he is in need of them. The marginal investor . . . and the one who operates at a loss during his first years of operation, will garner little or no benefits from the incentives which presumably were designed especially to attract him." The Effects of Taxation on Foreign Trade and Investment (United Nations) 20 (1950).

90. Adverse results might not be so severe with the present relatively small volume of foreign investment. But if total exemption had the stimulating effects that is claimed 
tempted to compete with one another in offering tax concessions to American corporations, thereby employing more regressive taxes against their local populations. ${ }^{91}$ In these ways a tax incentive strong enough to be of substantial benefit to American business would tend to create conditions at home and abroad that were incompatible with existing domestic policies as well as with the basic objectives of the Point Four program.

There is another fundamental weakness of tax exemption as a Point Four incentive. At best it can only increase foreign investment generally, rather than direct investment to specific countries and to specific parts of their economies. This failure can only be remedied by withholding tax exemption from all but certain governmentally-approved enterprises. An alternative remedy, perhaps administratively more feasible, would be to extend special subsidies to Point Four projects. The current preference for private investments, however, stems from the fact that it involves no cost to the American taxpayer and no necessity for government control. The first of these advantages is lost in any kind of tax incentive. Both of them are lost in selective tax exemptions and subsidies. If such measures are resorted to, it may be hard to defend the preference for private financing over direct financing by the government itself.

\section{The Antitrust Incentive}

The American corporations which must bear the main burden of a privately financed Point Four program ${ }^{92}$ are currently subject to United States antitrust laws in their foreign operations. ${ }^{93}$ These laws have been called a major barrier to private implementation of Point Four. ${ }^{94}$ American

for it, a considerable amount of the national income, particularly of the higher brackets, would go tax-free. Furthermore, no matter how large the actual amount of income involved "the [exemption] proposal would appear to be particularly ill-timed now when revenue requirements necessitate heavy burdens on income from domestic sources. Under conditions where the income tax, essentially self-assessed and self-administered, is relicd upon to yield most of the government's revenue, any damage to the public confidence in the equity and fairness of the income tax must be scrupulously avoided." Share, supra note 61 , at 825 .

91. As a result, exemption may be the cause of "taxes detrimental to cconomic development and rising living standards." Share, supra note 61 , at 826.

92. See note 60 sispra.

93. The principal statutes affecting U.S. business abroad are the Sherman Act, 26 StAx. 209 (1890), as amended, 15 U.S.C. \$1-7, 15 (1946); the Clayton Act, 38 STAт. 730 (1914), as amended, 15 U.S.C. $\$ 12-27$ (1946); the Federal Trade Commission Act, 38 Star. 717 (1914), as amended, 15 U.S.C. \$41-51 (1946); the Webb-Pomerene Act, 40 Stat. 516 (1918), 15 U.S.C. \$61-65 (1946); and the Wilson Tariff Act, 28 StaT. 509 (1894), as amended, 15 U.S.C. \$ 8-11 (1946). See generally, Hưgin, Puvate InTERnational Trade Regulatory Arrangements and the ANti-Trust laws (1949); Toulmin, The Law of International Private Agreements, 32 VA. L. REv. 335 (1946).

94. "The projection of the Point Four program throws into relief the manifest contradiction between the Antitrust Department's doctrinaire attack on international collaboration ... for American and foreign technical corporations and the fostering solici- 
business, it is argued, must be free to adjust to monopolistic conditions imposed abroad by foreign firms and governments. ${ }^{95}$ Whether this is a desirable way to promote foreign development, however, may be somewhat debatable. Changes in the antitrust laws may occasionally accord with the demands of some foreign governments. But at the same time they may be inconsistent with general foreign and domestic policies of the United States and in particular with the fundamental objectives of Point Four.

American foreign policy has been directed toward preserving freedom in international trade against private as well as governmental restrictions." This is an important reason for the extension of the American anti-trust laws to activities carried on beyond the territorial limits of the United States. ${ }^{97}$ Activities in foreign commerce are no longer safe from anti-trust prosecution if they affect trade in this country.93 Export associations will

tude of the State Department for the enormous extension of American direct investments." Sachs, supra note 47 , at 429 .

95. Id. at 430-1. See also Lockwood \& Schmeisser, Restrictive Business Practices in International Trade, 11 LAw \& Contearp. ProB. 663, 679 (1946): "There is a tide of opinion abroad which insists that foreign capital shall become more closely identified with the nation in which it is invested. ... Such adaptation would be rendered much more difficult if our laws at home threaten prosecution for acts in conformity with the loeal law. This would present an element of risk for which no compensatory adjustments could be made. By this treatment of private enterprise we place another risk in the way of private investment, and, by so doing, threaten the success of our Proposals [For Expansion of World Trade and Employment] as a whole." The continued growth of combinations in foreign trade have led some to conclude that monopoly is to a large extent inherent in the structure of the international market and that an attempt to combat it through the American antitrust laws is futile. See, c.g., Perkins, Carlels: What Shall We Do About Thent, 181 HaRPERs 570 (1944).

96. See, e.g., Chapter V of the Havana Charter For an International Trade Organization (U.S. Dept of State Commercial Policy Series 113 and 114). The United States is currently injecting anti-cartel clauses in its "Point Four" treaties. See Treaty of Friendship, Commerce, and Economic Development with Uruguay, Art. XIV 3., Mressage of the President to Congress, Executive D, 81st Cong. 2d sess.

97. The Sherman act was for a time thought inapplicable to activities taking place entirely outside the United States, following the opinion of Mfr. Justice Holmes in American Banana Co. v. United Fruit Co., 213 U.S. 347 (1909). Subsequent decisions held the Sherman Act applicable to foreign activity so long as it affected United States commerce. See, e.g., United States v. Aluminum Co. of America, 148 F.2d 416, 443 (2d Cir. 1945); United States v. National Lead Co., 63 F. Supp. 513, 524-5 (S.D.N.Y. 1945). Accordingly, several corporations have recently been prosecuted successfully for activities in foreign commerce. See note 98 infra.

International law recognizes the right of the United States to punish forcign violation of its anti-trust laws if the violation (1) was committed by a United States national, (2) affected a United States national or (3) exerted influence in the United States. See Briggs, The Law of Nations 275-276, 302-5 (1946).

98. See United States v. National Lead Co., 332 U.S. 319 (1947); Branch v. Federal Trade Commission, 141 F.2d 31 (7th Cir. 1944); United States v. General Electric Co., 1948-1949 CCH Trade CASEs 62,912 \62,352 (D.N.J. 1949); United States v. Timlicn Roller Bearing Co., 1948-1949 CCH Trade CAses \63,041 (N.D. Ohio 1949). 
be prosecuted as are other corporations if their foreign activities restrain commerce in the United States, artifically affect American prices, or restrain the trade of an American competitor..$^{99}$ Even foreign corporations will be prosecuted for violations abroad when these violations affect the United States, and their officers can be found within American jurisdiction. ${ }^{100}$ Carried to its logical extreme, the rule that restrictive practices abroad are illegal if they affect the commerce of the United States would proscribe all such practices wherever located. Few foreign economic agreements cannot be shown to influence American commerce in some respect. ${ }^{101}$

Extension of antitrust enforcement to foreign commerce has been coupled with more stringent interpretations of the antitrust laws themselves. As a result, some of the most typical forms of private participation in foreign commerce have been rendered suspect. Price fixing ${ }^{102}$ and market allocation ${ }^{103}$ have both been held illegal per se. The fact that parties to such agreements are in the relation of parent and subsidiary may no longer be enough to validate them. ${ }^{104}$ Nor will these agreements be saved simply because they are natural counterparts to an exchange of "know-how." 100 The exchange of future "know-how" may itself be unlawful. ${ }^{100}$ Finally, the mere power to exclude competition-even if unexercised-may be fatal. ${ }^{107}$

Agreements concluded with foreign governments or made in accordance with foreign legislation are frequent incidents to business operation abroad. But even these are illegal if they shut off the foreign market to other Amer-

99. See United States v. United States Alkali Export Ass. 86 F. Supp. 59 (S.D. N.Y. 1949); Webb-Pomerene Act $\$ 2,40$ Stat. 516 (1918); 15 U.S.C. $\$ 61$ (1946).

100. United States v. Scophony Corp. of America, 333 U.S. 795 (1948).

101. "It is a matter of conjecture ... whether under present day conditions understandings can be had with . . international combinations without their having reciprocal effect in this country." Schilz, Postwar Operations of Export Associations Under the Webb and Sherman Lawes, 31 VA. L. Rev. 613, 626 (1945). Compare Hoover, op. cil. supra note 28 , at 75 : "There can be little doubt that domestic cartelization and international cartelization are intimately inter-related."

102. Cf. United States v. Socony-Vacuum Oil Co., 310 U.S. 150 (1940).

103. United States v. National Lead Co., 332 U.S. 319 (1947).

104. Cf. United States v. Timken Roller Bearing Co., 83 F. Supp. 284 (N.D. Ohio 1949); United States v. Yellow Cab Co., 332 U.S. 218 (1947); Note, 24 N.Y.U.L.Q. REv. 901 (1949).

105. The exchange of patent rights, trade marks and technical information upon the manufacture and sale of a product is not illegal, since the essence of a patent is the granting of a limited monopoly. But if conditions beyond the terms of the patent monopoly are attached to the agreement, such as allocation of exclusive marketing territories for patented articles, the whole agreement will be invalid. See United States v. National Lead Co., 332 U.S. 319 (1947).

106. So-called "cross-licensing" agreements to exchange rights to futture discoveries are thought to have the same restrictive effects as marketing agrcements. Sec United States v. Aluminum Co. of America, 148 F.2d 416 (2d Cir. 1945); United States v. General Electric Co., 1948-1949 CCH Trade Cases \62,770 (S.D. N.Y. 1948).

107. United States v. Aluminum Co. of America, 148 F.2d 416 (2d Cir. 1945); United States v. Griffith Amusement Co., 334 U.S. 100 (1948). 
ican exporters ${ }^{108}$ or restrict imports into the United States. ${ }^{103}$ Concession contracts or other types of exclusive agreements may be made the basis of prosecution, even if they cause no actual injury to competitors, as long as they tend to close out potential American competition. ${ }^{110}$ A possible way around these prohibitions might be for American firms to conclude agreements with foreign governments through foreign subsidiaries. III But the parent corporation may still be held responsible for restrictive arrangements if it can be linked in some way to their negotiation. ${ }^{112}$

The threat of prosecution for such a wide range of typical activities in foreign commerce may constitute a major deterrent to private participation in Point Four. It may obstruct the exchange of "know-how" between American and foreign corporations, or make it difficult for American firms to cooperate in the projects of some foreign governments. But the exchange of "know-how" is desirable only if it results in greater efficiency, lower prices, and greater consumption. ${ }^{113}$ Cartels are particularly objectionable because they limit free access to resources and foster unhealthy concentrations of economic power. ${ }^{114}$ They may interfere with the ability of the United States and the underdeveloped countries to carry out commercial or even political policies. ${ }^{115}$ These results are the very opposite of those

108. If the agreement actually affected the foreign commerce of the UJ.S., the fact that a foreign government was involved would not in any way protect the American company. See United States v. Sielken, Equity No. 9-188 (S.D. N.Y. 1912).

109. See United States v. Sisal Sales Corp., 274 U.S. 268 (1927) and Vilson Tariff Act, 28 STAt. 509 (1894), as amended, 15 U.S.C. \$8-11 (1946).

110. See note 107 supra. See address of Attomey-General Berge, CCH Trude REg. REP. If 56,070 (1945) : "Our trade, whether of exports or imports, cannot grow if artels determine who may enter foreign markets, who may sell or buy in the American marliet, and what industries can or cannot exist here or abroad."

111. Domestic corporations have escaped liability for cartel agreement entered into by their foreign subsidiaries. See United States v. Aluminum Co. of America, 14S F.2d 416 (2d Cir. 1945). Cf. the comment of Hucrs, op. cit. stipra note 93, at 209: "It would seem that, in such a case, a court might have been justified in going bahind the corporate entity to determine the real parties in interest and the true nature and result of the arrangement. ..."

112. See United States v. Aluminum Co. of America, 142 F.2d 416, 441-2 (2d Cir. 1945).

113. Cartel agreements may reduce the speed with which technological developments are put into effect; or, by maintaining artificially high prices, they may prevent their benefits from being passed on to the consumer. BerGe, Cartels-Cralcexae to $A$ Fnes WordD c. 3-11 (1944); HugrN, op. cit. supra note 93, at 214; Knorr, The Problcm of International Cartels and Intergovernmental Commodity Agrecments, 55 YALE L.J. 1097, 1100-2 (1946).

114. See, e.g., Loftus, Middle East Oil: The Patterm of Control, 2 AImbte EAsT J. 17 (1948). The Federal Trade Commission has begun an inquiry into the foreign activities of American oil companies.

115. "[C]ertain fundamental decisions affecting our relations with the rest of the world have been formulated and put into effect by private groups. . . These decisions concerning our strategic materials, industries and trade, our Good Neighbor and cur European policies, our disposition of enemy property, considerations of espionage, secrecy and the 
which economic development of the backward areas is meant to achieve. Consequently, there should be no antitrust immunity for foreign practices of American business. Unrestrained private power in foreign development is a poor way to promote the objectives of Point Four. ${ }^{116}$

The full reach of the antitrust laws in foreign commerce is still undetermined.17 Therefore, the demand for exemption from these laws is frequently accompanied by an alternative demand that they be clarified, either by statutory amendment or by administrative declaration. Presumably, giving business greater certainty in its foreign operations might provide a minor stimulant to private investment. But there are serious dangers in attempting to impart certainty by statute. To be effective, the antitrust laws must prohibit general results-restraint of trade and monopolyrather than specific techniques of achieving them. It is difficult to produce certainty without creating loopholes through which the ingenious may circumvent the law.

Administrative surveillance of foreign activities might avoid this danger. Advance disclosure by corporations of doubtful agreements is a common suggestion. ${ }^{118}$ But the value of this device is limited by the fact that the full future significance of such agreements can seldom be anticipated. Consistent definition and application of the antitrust laws abroad may only be achieved with the establishment of a special administrative agency to police all activities in foreign commerce. In view of the increased emphasis on foreign investment under the Point Four program, such an institution deserves careful consideration. Here again, private enterprise cannot begin to implement Point Four without a considerable amount of government control.

evasion of our laws, have all been accomplished without the knowledge of our government or its acquiescence." BERGE, op. cit. supra note 113, at 230. These results from cartel operations are even more likely in an underdeveloped country. In the case of Middle East oil, "an industrial empire is established within the local state, sometimes even coterminous with it geographically. Subject to the limited and specific stipulations of the contract, this enterprise is almost autonomous; it has extensive rights which in other jurisdictions are frequently reserved to the state. The local government has . . . no control over the destinations to which its oil is shipped or the political ends such shipment may serve. . .." Loftus, supra note 114, at 26.

116. Despite the protests of foreign trade interests, the trend still seems to be toward more, rather than less, anti trust enforcement abroad. A bill introduced carly in 1950 would amend the WEBB ACT to increase the antitrust liability of export associations. Sce Hearings Before Subcommittee on Study of Monopoly Power, Committec on the Judiciary on H.R. 5041, 81st Cong., 2d sess. (Feb. 23, 24 and March 1, 1950).

117. See, e.g., United States v. Alkali Export Association, 86 F. Supp. 59,71 (S.D. N.Y. 1949): "[T] he possible legality of international agreements touching only forcign markets . . . has not been overlooked." But see note 101 supra.

118. At the present time, disclosure is sometimes rewarded with a promise of inmunity from criminal prosecution, but the disclosing corporation is still liable in a civil action. Furthermore, the Department of Justice reserves the right to change its mind as to the legality of the agreement. See Tmmberg, Tue Antr-Trust Laws fron the Point oy View of A Government Atrorney 42-3 (Practising Law Institute Pamphlet, 1949). 


\section{The Treaty Incentive}

One of the major incentives to private participation in Point Four requires assistance from the underdeveloped countries themselves. The very nations which most require investment aid have handicapped American business with a host of unfavorable controls and practices. Multilateral negotiations to ameliorate these restrictions have so far proved unsuccessful. ${ }^{119}$ As a result, the United States government has been urged to press directly for their removal through bilateral investment treaties. ${ }^{150}$

Assurance of better treatment from foreign governments might increase substantially the flow of private investment abroad. Investment treaties will not be effective Point Four incentives, however, if they eliminate foreign restrictions that are fundamentally consistent with the purposes of economic development. For this reason, each of the restrictions sought to be eliminated must be weighed on its merits. Furthermore, even those restrictions that seem unjustified must be removed with tact and caution. Point Four will not be successful if it is forced upon the underdeveloped countries against their will. ${ }^{121}$

119. Early in 1948, the Havana Conference of the International Trade Organization and the Ninth International Conference of American States at Bogota both devoted considerable time to restrictions on foreign investment. The resulting documents contained general investment provisions that were unsatisfactory both to capital-exporting and capital-importing nations. See LEwIs, op. cit. supra note 8, at 262-71.

120. See, e.g., National Association of Manufacturers, Tre Bold Nev PlasiA Prograar for Underdeveloped Areas 10 (1949); National Foreign Trade Couricth, Private Enterprise and the Ponst IV Prograas 11, 16 (1949). The specific treaty provisions desired by American business can be found in INTERNatrosial Cansmers of Commerce, Draft International Code of Fatr Treaturent fos Fomeign Investare:its (1949).

Negotiation of investment treaties has received official emphasis as an important element in Point Four. See the President's Point Four message to Congress, sipra note 17 , at 101 ; Departarent of State, sipra note 2, at 6S-9. A Treaty of Friendship, Commerce, and Economic Development was signed with Urusuay on Nov. 23, 1949. "The treaty . . . is appreciably broader in scope than existing United States commercial treaties in matters relating to the encouragement of economic and industrial development. It contains provisions designed to encourage the flow of capital, skills, and technological assistance. ... In this regard, the treaty is in accord with the general policy of this Government for the encouragement of the economic and industrial development of other countries." Dept. of State Press Release No. 916, Nov. 23, 1949.

121. "[W]e must make sure that [investment treaties] completely respect the individuality, the business mores, and the cultural preferences of other countries." Kreps, Point Four and the Domestic Economy, 268 Ansals 160, 168 (1950). Although economic assistance to the underdeveloped countries may make possible the removal of some controls, the sweeping provisions of the International Canuder of Comarsce, supro note 120 , have been criticized as bearing "curious similarity to those stipulated in the New Order' . . . which the German industrialists under the leadership of I. G. Farben considered necessary for 'fair treatment' in their negotiations with Austria, France, and other contiguous countries." Kreps, supra, at 168 n.12. Compare the assurances in the President's Point Four Message to Congress, sipra note 17, at 101: "In negotiating surh 
Restrictions on Ownership and Control. A common form of restriction imposed by the governments of the underdeveloped countries limits the power of foreign investors to own or manage local enterprises. In their most cxtreme form, such restrictions prevent investment by non-nationals in certain strategic industries, public utilities, or raw materials. ${ }^{122}$ More often they simply restrict stock holdings by foreigners in local enterprises-usually to a minority share. ${ }^{123}$ But American investors have not been anxious to share their profits. They complain that local control of business operations means reduced efficiency and undue preoccupation with quick returns. ${ }^{124}$ Ownership and management restrictions not only reduce the flow of private investment abroad by limiting the amount that can be invested in particular enterprises; they may deter some American firms from undertaking any investment at all. ${ }^{125}$ As a result, the elimination of these restrictions has been urged as a primary objective of investment treaties. ${ }^{120}$

Despite the fact that they reduce the amount of private investment abroad, most ownership and management restrictions are consistent with the political, economic and social purposes of the Point Four program. By forcing American investors to combine with domestic investors, they insure that profits from local resources are enjoyed locally. They reduce foreign exchange problems caused by the need to transfer earnings abroad. They help gain the cooperation of local business and government and

treaties we do not ... ask privileges for American capital greater than those granted to other investors in underdeveloped countries or greater than we ourselves grant in this country."

122. See Lewis, United States and Foretgn Investment Problems 159-61 (1948); Bonsal \& Borges, Limitations Abroad on Enterprise and Property Acquisition, 11 Law \& Contemp. Probs. 721, 724-7 (1946) ; Eder, Some Restrictions Abroad Affecting Corporations, id. at 715 .

123. See Coudert \& Lans, supra note 40, at 752-7; Reeves \& Dickens, supra note 6, at 230-1.

124. See, e.g., Reeves \& Dickens, supra note 6, at 231.

125. See the statement of Austin T. Foster, General Counsel, Socony-Vacuum Oil Co., Inc., at Point IV Forum, 36th National Foreign Trade Convention, p. 27 (1949). See aiso Reeves \& Dickens, stpra note 6, at 231: "American investors feel they cannot jeopardize their capital by a management over whom they have no control and in whose business judgement they may have little confidence."

126. The International Chamber of Commerce Draft Code, supra note 120, would abolish foreign restrictions on the nationality of shareholders or members of the board of directors (Art. VI). It would give foreign and domestic nationals equal rights to make investments with a possible exception for "investments immediately concerncd with national defense." (Art. III). The Herter Bill, H.R. 6026, called for treaty provisions to protect investors against "measures which unduly restrict the right of nationals of the United States to own, manage, and operate business enterprises within the participating country." (Sec. 11(a)(1)). Compare the Treaty with Uruguay, which grants equal treatment with nationals to foreigners engaging in certain enumerated enterprises but withholds it for investments in minerals; and which reserves the right to impose specific limitations on occupations engaged in by particular aliens. (Art. V, 1,2,3). 
frequently reduce the appeal of native nationalism. ${ }^{127}$ It is desirable to find a way to retain these benefits and yet alleviate the worst fears of American business. One method may be joint ownership of enterprises under temporary American management, with ownership and control gradually devolving upon domestic nationals. ${ }^{123}$

Restrictions on Employment. Foreign laws providing for employment of local labor and technical personnel represent further attempts by the underdeveloped countries to preserve for themselves the fruits of development. ${ }^{129}$ Employment of local personnel, especially on the technical and supervisory level, assures the spreading of skills and "know-how." 123 It increases local employment and income. In addition, it helps adapt foreign enterprise to native life. ${ }^{131}$ These results are all basic to the Point Four program. But American business has urged treaties to relax these controls on the grounds that an efficient staff cannot always be recruited from local personnel. ${ }^{132}$ Where labor restrictions make it impossible for foreign enterprise to operate at all, some modification may be desirable. ${ }^{133}$ In most cases, however, these restrictions accord too closely with the interests of the underdeveloped countries to make their elimination by treaty either feasible or advisable.

Minimum wage laws and other social legislation in foreign countries have

127. These advantages of joint enterprises are summarized in Coudert \& Lans, supra note 40, at 752-7. Compulsory partnership with local nationals is regarded favorably by the Economic and Employment Subcommission of the Economic and Social Council. See Econonic and Social Councri, supra, note 5, App. IV. pp. 12-13.

128. For recent examples of arrangements for local control coupled with temporary American management, see Business Week, Feb. 19, 1950, p. 117. Some underdeveloped countries are willing to allow administrative and executive control by foreigners provided that provision is made for the eventual transfer of this control to domestic nationals. See, e.g., Statement of Industrial Policy of the government of Pakistan, U.S. Dept. of Commerce, Laws Regulations Policies and Practices Affecting Private Foreign Investment in Pakistan, App. IV, p. 8 (Feb. 15, 1949).

129. See, e.g., LEWIS, op. cit. supra note 8 , at 156-9.

130. "The greatest needs of the peoples of the underdeveloped areas are to learn the significance of individual freedom and to acquire the ability to develop their own resources. Both of these are primarily educational processes. . ." Bowles, supra note 13, at 140. The importance of training local labor in technical skills is stressed in Eco:ousc sid Soctal CouncII, stpra note 5, App. IV (Report of Sub-Comm. on Ec. Devel.), 11-13.

131. "Suspicion of economic imperialism is least likely to attach to those enterprises which manifestly seek transferred responsibility and initiative at the earliest possible opportunity." Bowles, supra., note 13. Hiring a number of local citizens as supervisory employees may bridge the "psychological gap" between foreign business and the native population. See Coudert \& Lans, stpra note 40, at 750-1.

132. The International Chamber of Commerce Draft would allow foreign enterprises to bring with them all the "administrative, executive and technical officers and staff" which they require. (Art. VI.)

133. The Treaty with Uruguay permits free choice by foreign enterprises of technical experts, executive personnel, and other specialized employees, regardless of nationality. (Art. V, 4). 
also met with objections from American business. Allegedly, they make operation inconvenient and expensive. Social legislation may not always be compatible with economic development: if labor's share in the national product is raised too rapidly, investment funds may not be forthcoming. ${ }^{134}$ But the power to allocate resources between labor and capital, consumption and investment, is one which the local government will not want to relinquish. Attempts to hamper social legislation by negotiation of treaties are likely to, invite antagonism from the peoples as well as from the governments of the underdeveloped countries. ${ }^{135}$ Such efforts will frequently be inconsistent with programs of social legislation being carried on simultaneously in the United States.

Restrictions on Earnings. The underdeveloped countries employ a number of measures which restrict the earnings of foreign business. The general form of these restrictions is a high income and profits tax. Sometimes an absolute limitation is put on the rate of profit that can be enjoyed by foreign enterprises. ${ }^{136}$ These measures often provide a vital source of revenue. ${ }^{137}$ Business may also be required to reinvest earnings in the same or in other local enterprises, and thus make a concrete contribution to local productive capacity. ${ }^{138}$

While such restrictions are obviously discouraging to foreign investors, proposals to eliminate them by treaty have serious shortcomings. Existing treaties frequently provide for equal treatment in taxation with domestic nationals, and for taxation only of those profits fairly attributable to local production. ${ }^{139}$ But tax rates can impose a heavy burden on foreign enterprise without being technically discriminatory. Taxation of all profits above a certain absolute amount, for example, might affect only large American corporations. The United States government has been urged to oppose such measures. ${ }^{140}$ It cannot easily do so, however, without seeming to dictate

134. See, e.g., Reeves \& Dickens, supra note 6, at 232-3.

135. "Capital investment in these areas is essential, but it must be capital investment conforming to proper regulations protecting the interests of the people, and particularly the rights of the workers in the resulting enterprises. It must come, also, not as a substitute but as a supplement to the efforts of the people themselves in solving their own political and economic problems." Manifesto of the International Confederation of Free Trade Unions passed in London, December 1949, quoted in Hearings on Point Four Bill, supra note 23 , at 438 .

Provisions for paid annual vacations to native workers and for insurance against discharge without just cause were included in the Bogota Convention (Art. 32) upon the insistence on capital-importing countries. The United States filed reservations to both these provisions. See LEwIs, op. cit. supra note 8, at 268-9.

136. The limitation may impose a maximum rate of return for the forcign firm in its local activity, or a limit on the percentage of profits that can be remitted abroad. See Reeves \& Dickens, supra note 6, at 235.

137. See The Effects of Taxation on Foreign Trade and Investment (United Nations) 4 (1950).

138. Reeves \& Dickens, supra note 6 , at $167,236$.

139. See, e.g., Treaty with Uruguay (Art. IX, 1, 3).

140. "[T]here should be no de facto discrimination against American enterprises . . . 
matters of internal policy. Moreover, the purpose of Point Four would be frustrated if pressure were exerted on underdeveloped countries to employ low and regressive taxes, causing native resentment and permitting an inordinate proportion of the national income to be drained away to foreign investors. ${ }^{141}$

Restrictions on Convertibility. Exchange controls are a prevalent form of government restriction in the underdeveloped countries. ${ }^{142}$ These controls are usually employed to correct a deficit in the balance of trade. They are often necessary to prevent the flight of capital and the purchase of nonessential imports that threaten to occur in the early stages of development. ${ }^{143}$ By blocking the transfer of earnings and capital, however, exchange controls discourage private investment in the backward areas. ${ }^{144}$

Negotiation of special provisions on exchange control is held to be an essential step toward the achievement of Point Four. ${ }^{145}$ Existing treaties already require that exchange controls be used only under stringent con-

by subjecting them to scales of rates which are so graduated as to affect such corporations and not, in general, those owned by nationals of the country." National Forcign Trade Council, supra note 10 at 21. The Herter Bill, H.R. 6026, See $11(a)(2)(c)$, would have made Point Four aid conditional upon the conclusion of a treaty committing the underdeveloped country to pay compensation where it "imposes restrictions or charges on [foreign] property or business (eveln though on a mondiscriminatory basis) to such an extent as to deprive [the owners] of any substantial beneficial interest thercin." (Emphasis added.) It is interesting to note that no principle of international law prevents discriminatory taxation against aliens, whether de facto or de jure. See $1 \mathrm{HYDE}$, IrTERNATTONAL LAW 664 (2d ed. 1945).

141. "Perhaps the most important measure required in this area [to promote development beneficial to the underdeveloped countries] is the re-investment of profits or else the absorption of profits by fiscal measures. ..." Singer, The Distribution of Gains Between Investing and Borrowing Countries, 40 Asr. Ecos. Rev. 473, 484 (1950). See also The Effects of Taxation on Foreign Trade and Investment (United Nations) 5 (1950). "[T]ax privileges granted in the past to powerful foreign enterprises have often been the forerunner of anti-foreign sentiments and legislation which have barred the entry of foreign traders and investors in many countries more effectively than the equal administration of general tax laws would have done." Id. at 19. Private investment already receives a great deal of preferential treatment in underdeveloped countries, either by general legislation or by special arrangements between investors and governments. See id. at 22-5, 26-33. In Iran, for example, the Anglo-Iranian Oil Company received immunity from Iranian taxation during the first fifteen years of its concession (1935-48); in return, it agreed to make a substitute payment based largely on the amount of oil produced. This payment amounted to $\$ 3.3$ million in 1946 . In the same year, the United Kingdom's income tax on the company's profits amounted to $\$ 10$ million. Id. at 29.

142. See, e.g., LEwIS, op. cit. supra note 8, at 148-50.

143. See note 37 sipra.

144. See Reeves \& Dickens, supra note 6, at 238-9.

145. "The protection that the American investor would require before venturing with his funds into a foreign country amounts to a pledge of nondiscrimination plus specified exemptions from trade restrictions.... [T] hese are matters which, exceptional cases aside, no investor can settle with the foreign government; it is the proper object for negotiations and agreement between the United States and forcign governments." Heilperin, Private Means of Implententing Point Four, 268 Anwass 54, 60-1 (1950). 
ditions and in a manner which does not discriminate against the commerce of any nation. ${ }^{146}$ These provisions are not much help to American business. As a result, proposals have been made to exact an unqualified commitment for service of capital; or alternatively, absolute priority or priority second only to "essential imports." 147 Another and roughly equivalent suggestion would require free convertibility for service of capital until foreign exchange receipts fall below a specified amount. ${ }^{148}$

Provisions of this kind are likely to cause hostility and hardship. Giving foreigners exchange priority over domestic nationals would be less than popular with the peoples of underdeveloped countries. Moreover, the provisions would force the governments of those countries into an undesirable strait-jacket. To be a significant aid to foreign investment, the term "essential imports" would have to exclude capital equipment and include only those supplies necessary for a minimum standard of living. ${ }^{149}$ Yet this might prevent a domestic government from hastening its own development program or from enabling its people to gain some current benefits from economic expansion-benefits which they desperately need. ${ }^{160}$ Consequently, specific

146. See Treaty with Uruguay (Art. XV, 3, 4). Neither of these provisions goes far enough for private investment. Conditions of stringency are usually determined by the capital-importing country alone. The promise to employ controls in a non-discriminatory fashion is equally incapable of enforcement. If dollars alone are in short supply, demand will have to be directed away from American imports. The United Nations itself has found it necessary to "discriminate." See U.N. Will Favor Soft-Currency Area in Buying, N.Y. Herald-Tribune, March 2, 1950, p. 16, col. 3.

147. The Herter bill, H.R. 6026, Sec. 11(b)(1)(B), called for a Treaty of Convertibility in which an underdeveloped country would undertake "an unqualified commitment of convertibility [into the investor's currency or other currency acceptable to him] for the service on capital or . . . a commitment of convertibility into such currency with either priority in the highest category or priority second only to essential imports." These provisions are identical to those suggested by the National. Foreign Trape Councir, supra note 10, at 25. Capital service, as defined in the Herter Bill, Sec. 11 (b) (2) (A) "includes stipulated interest and amortization charges on loans, dividends on stock or comparable equity interest, profits, engineering and management service fees, royalties, copyright fees, but such term does not include except, in the case of amortization of loans, the transfer of capital as such ..."

148. Since the specified amount would be defined in relation to the need for "essential imports," there seems little difference between the two provisions. See Economic AND Social Council, supra note 5 (Report of the Sec.-Gen.) 30-1.

149. The Herter Bill, H.R. 6026, Sec. 11(b) (2) (B) defined "essential imports" to include "only food (including seeds, fertilizer, agricultural machinery and other supplics essential to the reduction of food imports), fuel, and supplies for shelter and the cure and prevention of disease, and such imports only in such volumes as may be essential to the maintenance of an accepted standard of living." Capital goods for development were specifically excluded from this category. Ibid. The same definition was suggested by the National Foreign Trade Council, sipra note 10, at 26-7.

150. Holding people to a minimum standard of living may also hold down their productive capacities. The opportunity to gain more than life's bare essentials creates an incentive for labor. Further, an improved diet may provide a significant stimulus to productivity. See Stearns, The Road that Food Built, Harpers, June 1950, p. 82. 
provisions which give private investors a fixed claim on an underdeveloped country's foreign exchange seem incompatible with the fundamental purposes of the Point Four program.

Government Expropriation and Government Competilion. The prospect that property held abroad will be taken by foreign governments without adequate compensation has become an increasing deterrent to private investment. ${ }^{151}$ Expropriations in the past were isolated events. Now they are coordinated to meet the requirements of partial or total nationalization programs. A commitment to refrain entirely from expropriation seems

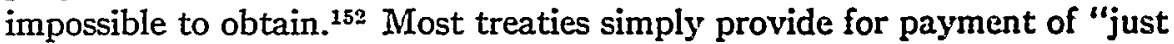
compensation in a prompt, adequate and effective manner" in the event that expropriation occurs. ${ }^{153}$ These vague provisions are interpreted according to local law. ${ }^{154}$ As a consequence, the private investor has little assurance of how much, when, or how he will be paid. Business has long sought adoption of the principle that compensation be paid in the currency of the expropriated investor. ${ }^{155}$ This principle is not acceptable to the underdeveloped countries; it faces the same objections that are made to specific commitments for convertibility. The best compromise that can be hoped for seems to be a promise of eventual convertibility at the rate of exchange existing when expropriation occurs. This would at least avoid the additional hazards of depreciating currencies.

Complete or partial socialization abroad may mean not only outright

151. See LEWIS, op. cit. supra note 8, at 150-6.

152. The investment provisions of the ITO Charter failed to provide security from expropriation. Although the ITO members pledged themselves not to take "unreasonable or unjustifiable action" against foreign investment (Art. 11, par. 1 (b)), they reserved the right "(i) to take any appropriate safeguards necessary to ensure that foreign investment is not used as a basis for interference in internal affairs or national policies; (ii) to determine whether and to what extent and upon what terms [they] will allow future foreign investment; (iii) to prescribe and give effect on just terms to requirements as to the ownership of existing and future investments; (iv) to prescribe and give effect to other reasonable requirements with respect to existing and future investments." (Art. 12). See Havana Charter, sipra note 96; Ecosossic ANd Socinl Couscrl supra note 5, (Report of the Secretary-General) at 29; ICC Draft Code, supra note 120, at 17-19.

153. See, e.g., Treaty with Uruguay (Art. VIII, 2). The Bogots Agreement (Art. 25) similarly provided that "an expropriation shall be accompanied by payment of a fair price in a prompt, adequate, and effective manner." See LEwrs, op. cit. supra note 8, at 268 .

154. Eight South American countries filed reservations to the Bogota Agreement stating that the expropriation provisions, supra, were to be subordinated to the provisions for expropriation provided in the constitutions of the signatory countries. Id. at 268-9. The ICC Draft Code states by contrast that "fair compensation" be paid "according to international law" (Art. XI a) and provides, in the event of an impasse, for interpretation by an International Court of Arbitration (Art. XIII).

155. The Herter Bill, H.R. 6026, Sec. 11(b)(1) (A), following the lines of the ICC Draft Code (Art. XI, c, d) provided for "an unqualified commitment of convertibility of the proceeds of just compensation .... into the currency of the investor's country or other currency acceptable to him. ...." 
expropriation but competition with private firms by government-owned or government-subsidized enterprises. ${ }^{156}$ The interests of American business are currently represented in bilateral treaties by provisions that government enterprises should occupy the same status before the law as private competitors, and that they should conduct business according to purely commercial considerations. ${ }^{157}$ In practice, such provisions are of little value. Consequently, American trade interests have asked for a specific commitment by foreign governments to pay compensation not only for expropriation but also for injury due to government competition and other government action. ${ }^{158}$ Thus business is demanding privileges abroad that have been expressly denied it in the United States. ${ }^{169}$ In an era of increasing government participation in economic life, these demands are likely to produce much resentment and negligible results.

Subjection to Local Jurisdiction. With the demise of extraterritorial rights, ${ }^{160}$ investors in foreign countries have become almost entirely subject to local law. ${ }^{161}$ Treaties usually provide for equal treatment with local nationals in protection of an alien's person, rights, and property. ${ }^{102}$ Equal treatment is not enough to satisfy American business, however, when less favorable treatment is received in foreign courts than would be accorded at home. Since legal protection may be particularly inadequate in underdeveloped countries, private participation in Point Four is likely to revive the demand for treatment of aliens that measures up to a satisfactory "international standard." ${ }^{163}$ It has yet to be decided, however, just what

156. See, e.g., LewIs, op. cit. supra note 8, at 164-5.

157. See Treaty with Uruguay, Protocol 1 and Art. XIV, 1. But government enterprises may be given more favorable treatment where they are "supplying, at prices substantially below competitive prices, the needs of particular population groups for essential goods and services not otherwise practically obtainable. ..." (Protocol 1.)

158. Almost identical provisions to this effect were contained in the Herter Bill, H.R. 6026, Sec. 11(a) (2), and in Natronal Foreign Trade Council supra note 10, at 16.

159. Private firms have been refused compensation for alleged injuries due to United States government competition. See Alabama Power Co. v. Ickes, 302 U.S. 464 (1938). They have also failed to recover for alleged injuries due to reasonable administrative action. See Perkins v. Lukens Steel Co., 310 U.S. 113 (1940).

160. Extraterritoriality enabled citizens of Western nations travelling or residing in certain non-Christian countries to have their disputes settled by their own judges according to their own laws. See Brown, Exterritoriality, 6 ENcyc. Soc. Scr. 36-9 (1938).

161. See, e.g., BRIGGs, op. cit. supra note 97, at 501-2, 507-9; LEwIs, op. cit. supra note 8 , at $180-1$.

162. See, e.g., the Treaty with Uruguay (Art. II, 1).

163. See BrIGGs, op. cit. supra note 97, at 507-9. The Bogota Agreement (Art. 24) provided that policies adopted toward foreign investments must be effectuated "within a system of equity and of effective legal and judicial guarantees." See LEwis, op. cit. supra note 8, at 268. Compare the provisions (Art. V) of the ICC Draft Code: "Should the nationals of one of the High Contracting Parties not enjoy the full benefit of the civil rights generally recognized by the other High Contracting Parties or by international law, the nationals of the other High Contracting Parties shall be entitled to such rights and this protection shall not be denied to them on the ground that a preferential system 
fundamental rights of Americans are to be enforced abroad, and whether they should be insisted upon even against the wishes of the local population. The problem is particularly acute in cases of foreign expropriation. Past attempts to enforce American concepts of due process in controversies abroad have not improved business dealings or international harmony. ${ }^{164}$ As a result, the United States may now be precluded from diplomatic intervention in some countries at least until local remedies have been exhausted. ${ }^{165}$

The limitations of treaty provisions in this field have led American business to seek an expansion of commercial arbitration. ${ }^{10 s}$ Settlement of trade disputes by private arbitrators, however, means less control over foreign development by the underdeveloped countries and by the United States. It may mean enforcement of cartel agreements or other policies which are incompatible with the objectives of Point Four. ${ }^{167}$ The need to combine responsibility in foreign development with security for private investment may require the establishment of a new International Court for the handling of trade disputes. ${ }^{163}$

Summary. Negotiation of investment treaties will not overcome the obstacles to private participation in Point Four. Although present treaties do not satisfy private investment, few significant safeguards can be added without doing violence to the objectives of foreign development. ${ }^{100}$ Most would thus be established in their favour." (Emphasis added). This provision goes further than enforcing an "international standard"; it seems almost a partial return to extraterritoriality. See note 160 supra.

164. See STALEY, op. cit. supra note 40 , at $435-454$.

165. The "Calvo clause," included by many South American countries in their constitutions, statutes, treaties, or contracts with foreign investors, makes resort to local courts and renunciation of diplomatic protection a condition of doing local business. Sce Borchard, Protection of Foreign Invesiments, 11 LAv \& Costessp. Pros. 835, 846-847 (1916). The effectiveness of this clause in altering alien rights under intemational law has long been a subject of controversy. See Brigss, op. cit. supra note 97, at 541-2. It would seem that an alien must at least avail himself of existing local remedies before he can pursue an international claim. See United States (North American Dredging Co. Claim) v. United Mexican States, United States-Míexico, General Claims Commission (1926), reprinted in id. at 524-33.

166. See Rosenthal, Arbitration in the Settlement of Intenational Trade Dispufes, 11 LAW \& CONTEMrP. PROB. 808 (1946). "[T] he international merchant needs legislation in most countries of the world which will insure universal recognition of the validity of the arbitration clause, which will adequately define the powers of the arbitrators in all jurisdictions and which will enable the enforcement of foreign arbitration awards in the jurisdictions of the losers." Id. at 833.

167. See Kronstein, Business Arbitration-Instrument of Private Goucrnment, 54 YALE L.J. 36, 56-57 (1944).

168. The present International Court of Justice is empowered to consider only disputes arising between states, not those arising between individuals. Statute of the International Court of Justice, Art. 34 (1). Further, the Court has no special competence in the freld of commercial relations. Thus a new international institution would be needed. See LEwIS, op. cit. supra note 8, at 260-2; Coudert \& Lans, supra note 40, at 758.

169. The treaty with Uruguay grants private investment substantially all the safe- 
foreign controls and practices are either economically justified or too deeply rooted in public demand to make an assault on them advisable. The concessions private enterprise wishes the United States to exact would put this government in frequent opposition to measures of social reform and national interest. The very system of negotiation would direct capital toward countries offering the greatest concessions rather than those offering the greatest possibilities for development. Finally, the proposed investment treaties would exact assurances from the underdeveloped countries without giving any assurances in return. As a result, they seem particularly far removed from the original conception of Point Four. ${ }^{170}$

\section{The Guarantee Incentive.}

The shortcomings of all the previous proposals have paved the way for a new and more extreme kind of incentive. To break the bottleneck, the United States government would guarantee American firms against the risks peculiar to their foreign investment. ${ }^{171}$ This proposal accepts the in-

guards that are desirable. Analysis shows the practical limitation of these provisions. No great stimulus to private investment can be expected from inclusion of similar provisions in treaties that are still below the Uruguayan standard.

170. "Guaranties to the investor must be balanced by guaranties in the interest of the people whose resources and whose labor go into these developments." Point Four address of the President, supra note 1. The mutuality of obligations in Point Four development is recognized in the Point Four bill, H.R. 7346, Sec. 2 (c): "Technical assistance and capital investment can make maximum contributions to economic development only where there is ... due respect for the legitimate interests of the peoples of the countries to which the assistance is given ... and of the countries from which the assistance and investment are derived. In the case of investment this involves confidence on the part of the people of the underdeveloped areas that investors will conserve as well as develop local resources, will bear a fair share of local taxes and observe local laws, and will negotiate adequate wages and working conditions for local labor." Even if investors gave such "guarantees," how could they be enforced? Furthermore, when an underdeveloped country signed an investment treaty, what assurance would it have that "any American capital would actually be invested, that any American goods or technical processes would actually be made available, or that anything at all would happen ..."? WArnuro, "Point Four"-Our Chance to Achieve Freedom From FeAr 40 (1950). Although these considerations are important, they will receive little attention if businessmen are permitted to write Point Four treaties in the same way as they would a commercial loan. See, for example, the statement of N. A. Bogdan, supra note 43, at 6: "Foreign countrics must . . . be led to understand that when someone who really wants to borrow gocs to a bank to raise a loan, it is the bank and not the borrower which sets the terms. After all, we do not have to make investments abroad."

171. President Truman introduced the guarantee proposal in his Point Four message to Congress, supra note 17, at 101-2. The reasons for the proposal are described in DEPARTMENT of STATE, supra note 2, at 73: "The deterrents to private investment abroad cannot be completely removed by investment treaties, by tax incentives, or by teclunical advance alone. Certain risks peculiar to investment abroad ... will remain excessive from the point of view of U.S. investors. For example, although a treaty may assure no discrimination against U.S. investors seeking to remit profits, it cannot assure that sufficient dollars for that purpose will actually be available. . . . The extension of guaran- 
evitability of foreign restrictions; it commits the American government to make good the losses its citizens suffer as a result of them. Since guarantees would only be granted to firms whose operations fitted Point Four requirements, ${ }^{172}$ the proposal would avoid the defect of those incentives which only spur investment generally rather than direct it for specific purposes.

The success of the guarantee program as an incentive and its cost to the American taxpayer both depend on the risks against which guarantees are to be given. A current proposal would guarantee American investors against losses suffered as a result of expropriation or exchange control.173 Limited guarantees of this kind have done little to stimulate private investment in the past. ${ }^{174}$ They offer incomplete protection against the wide variety of hazards that face the foreign investor. A guarantee against expropriation, for example, does not help an investor who is put out of business by government subsidized competition or by confiscatory taxation. A guarantee against inconvertibility of currency will not encourage the investor who is deterred by the prospect of war or internal violence. To be more than a gesture, a guarantee program would have to protect investment against all, or most of these contingencies. ${ }^{175}$ Such a program would raise

tees by the U.S. Government against risks peculiar to investment in forcign countries is a means of attacking these difficulties. ..."

In the summer of 1949 the Administration introduced identical bills, S. 2197 and H.R. 5594, amending the Export-Import Bank Act, 59 StAт. 526; 61 StAT. 130 (1945) to cnable the Bank, in addition to its other functions, to "guarantee United States private capital invested in productive enterprises abroad which contribute to economic development in foreign countries against risks peculiar to such investments." See Hearings Before the Committee on Banking \& Currency on S. 2197, 81st Cong., 1st Sess. (1949); Hearings Before the Committee on Banking \& Catrency on H.R. 5594, S1st Cong., 1st Sess., 19, 22, 23, 24 (1949). The bills were subsequently amended by inserting in place of "against risks peculiar to such investments" the following: "by assuring either or both (i) the conversion into United States dollars of foreign currency derived from an investment and (ii) compensation in United States dollars for loss resulting from expropriation, confiseation, or seizure"

172. "In issuing guarantees the [Export-Import] Bank will give full consideration to the contribution that the investment can be expected to make to economic development. Furthermore, we do not intend to impose our own plans of economic development on foreign countries, and we would not, therefore, guarantee investments if those countries themselves did not consider that the investment would make a contribution to their ceonomic development." Under-Secretary of State Webb in 21 Dep't STATE BuLL 305, 316 (1949).

173. See note 171 supra.

174. The Economic Cooperation Administration was authorized to guarantee private investments against loss through non-convertibility up to the amount of $\$ 300$ million in 1948 and $\$ 150$ million in 1949. As of Aug. 1,1949 , only $\$ 2.7$ million in industrial guarantees were outstanding, and only $\$ 12.5$ million in guarantee applications vere under consideration. See Hearings, stpra note 171, at 22. It is true, of course, that the proposed guarantee would compensate for losses from expropriation as well as from exchange control. It is also true that guarantees might be more widely used by private business in underdeveloped countries where the risks are greater than in Western Europe. See Business Week, Feb. 19, 1950, p. 118.

175. One proposal presented to Congress would provide U.S.-guaranteed compensation 
perplexing administrative problems-how to determine to what extent foreign controls and practices were responsible for financial loss. Moreover, it is doubtful that the United States government would want to guarantee investors against ordinary business risks, ${ }^{176}$ or against the same forms of government activity from which they receive no protection at home. ${ }^{177}$

A guarantee program large enough to achieve significant results would have to be extremely expensive. There is no apparent way of offsetting the cost. Investors who received guarantees could, of course, be made to pay insurance premiums. But it is difficult, if not impossible, to assess premiums for risks of this kind. Insurance schemes are effective only when they cover predictable risks and non-related events. The risks facing foreign investment, such as expropriation or war, are unpredictable and cumulative in nature. The sudden activity of one government could wipe out millions of dollars of guaranteed investments. To be even roughly commensurate with the risks involved, premiums would have to be extremely high. In that case, the program would not be attractive to private investment. There seems no way to avoid the necessity for substantial appropriations of government funds. ${ }^{178}$

Despite its high cost, a guarantee program provides no assurance of success. The program is regarded with disapproval by most representatives of American business, mainly because of the extensive role that government would have to play. ${ }^{179}$ There would be little point in guaranteeing projects which were not approved both by the underdeveloped country and the United States. ${ }^{180}$ A certain amount of continued supervision would be required to assure that actual operations accorded with the specifications of Point Four. It is doubtful that many American firms will want to submit to possible control by two governments.

The results of a guarantee program would be novel and disquieting. The American government, having reimbursed a private investor for his losses, would itself pursue the private claim against the foreign govern-

for "any law, ordinance, regulation, decree, or administrative action . . . which . . . prevents the further transaction of the business for which the guaranty was issued." Sce Statement of Norman M. Littell, Hearings, supra note 171, at 87.

176. See Department of State, supra note 2, at 74.

177. See note 159 supra.

178. These funds would probably reduce amounts available for direct government lending. So far, the administration has requested no new appropriation for guarantec activity. But to the extent that the Export-Import Bank sets aside uncommitted funds for the guarantee program, it will have less funds with which to make loans to foreign governments. See the criticism on this ground by Norman M. Littell, Hearings, sttpra note 171, at 92 .

179. See, e.g., National Foreign Trade Councit, supra note 10, at \&-9: "[T] he Council does not recommend the inclusion of 'guarantees' by the United States Government. . . . It is convinced that 'guarantees' would tend either toward undite regulation by the United States Government of American private enterprises operating abroad or toward undesirable involvement of the United States government in business."

180. See note 172 supra. 
ment. 181 Diplomatic negotiation over what is "fair" compensation or what is "discriminatory" legislation is likely to be complex and protracted. ${ }^{182}$ It will not contribute to international good will. There is the additional danger that the United States, faced with a threat to guaranteed investments abroad, would be tempted to intervene in favor of the stalus quo. ${ }^{133}$ Although a program of public investment would involve similar problems, it would at least provide greater control over the source of controversy. A guarantee program, on the other hand, would involve national interests and national prestige in disputes of private origin. Consequently, it has all the shortcomings and few of the advantages of direct investment by the government itself.

\section{Planning for World Developarent: the Rational Adaption of Means To Ends}

Present plans for implementing Point Four do not bear the test of examination. Tax, antitrust, treaty, and guarantee incentives are unlikely to cause a significant increase in foreign investment. They are less likely to spur investment in directions required by Point Four. In some ways, they may even conflict with the basic purposes of the program. Consequently, private enterprise cannot be given primary responsibility for foreign economic development. If Point Four's political, economic and humanitarian goals are to be achieved, an alternative source of capital investment will have to be found. 184

The main burden of Point Four will have to be carried by the United States government itself. ${ }^{185}$ Only direct public financing can overcome the

181. See the Statement of Secretary Snyder, Hearings, supra note 171, at 10.

182. See, e.g., the variety of questions raised in Econossic \& Socinz Couricin, supro note 5 (Report of the Secretary-General), at 33.

183. "[Y] ou make these investments and then there is a change in government or a threat of a change in government, and, of course, since we have guaranteed the stability of that government we use the force of our Government to keep in power the government that has been friendly to us and a government which may have become unpopular with the people of that country." Statement of Rep. O'Hara, Hearings on H.R. 5504, supro note 171, at 55. Compare the answer of Under Secretary Webb: "I should like to state for the record as forcefully as I can that. whatever may have been our mistakes in the past, it is the policy of this Government not to intervene in the domestic affairs of forcign countries. Whether or not this Government undertakes a guarantee program, that policy will not be altered." Id. at 56 .

- 184. "To wait upon private capital (even when it is buttressed by guarantces of convertibility, tax help and the like) is to allow the future of the underdeveloped areas to be dependent on a very uncertain quantity. ... To wait upon this uncertain element to do a job whose suecess depends on a fairly steady increase of investment and income, and the hope, opportunity and freedom that go with that, is to give up the whole program in advance." Anderson and Rausgendush, A Policy and a Prograss for Success 50 (Public Affairs Institute, Bold New Program Series No. 1, 1950).

185. " $[\mathrm{H}]$ ere and now the decision to extend aid is political. In other words, it is the United States and the Commonwealth Governments that must decide to act." The Economist, Jan. 14, 1950, p. 59. The point is similarly expressed in Hanris, Forerc: 
obstacles blocking foreign development by private means. Government investment is needed to offset the political risks and the nationalist hostility that presently deter American business. It is needed to carry out unprofitable, long-range development programs. It is needed to guide development in the interests of the backward peoples rather than by purely commercial considerations. A program with such far-reaching political, economic, and social effects must be carried out by an institution capable of planning in the public rather than the private interest.

Public financing alone, however, will not insure the success of Point Four. Unsupervised loans and grants may not be used economically. The governments of the underdeveloped countries are less likely to make efficient use of investment funds than the recipients of the Marshall Plan. ${ }^{180}$ In some: countries, investment may be dissipated on consumer goods, leaving the population increasingly dependent on American aid. In others, it may be channelled too rapidly into heavy industry. ${ }^{187}$ Close control must be maintained to see that investment is employed for diversified development and for productive purposes. Moreover, investment in these areas must bc accompanied by widespread industrial and agricultural reforms. Direct intervention may even be necessary to insure that the primary benefits of development are enjoyed by the whole population rather than by a privileged few. ${ }^{188}$

Aid and the Anerican Economy 13 (Public Affairs Institute, Bold New Program Series No. 7 1950): "Where the gains accrue largely to the nation generally, then the disburser of funds has to be the government." It seems unreasonable to expect private investors to "see the necessity for undertaking investments in the underdeveloped countrics as an obligation imposed on them in the interests of world economic development, of the promotion of world peace, and of the achievement of the objectives of the United Nations." Economic \& Soctal Council, supra note 5, App. IV (Report of Subcomm. on Ec. Devel.) 14. Foreign lending, having become a vital instrument of foreign and domestic policy, can no longer be left entirely to individuals. See Buchanan \& Lutz, Rebuilding the WontD ECONOMY 160-77 (1947).

186. "The institutions, the traditions, the administrative framework which made the Marshall Plan effective, hardly exist in Asia." The Economist, Jan. 21, 1950, p. 114. The same can be said of the other underdeveloped areas. See also The Economist, Jan. 14,1950 , p. 58: "[T] he underlying dilemma remains between the insufficient numbers and insufficient experience of Asian officials and businessmen responsible for development and the nationalism which forbids too great a dependence upon outside instruction, experience and advice."

187. See The Economist, Jan. 14, 1950, p. 59, and note 57 supra.

188. "[T]o put American money into development of technologically backward areas while leaving as they are the internal distribution of wealth and power and the existing relation between the small omnipotent minority and the impoverished majority is to aggravate conditions already so bad as to be volcanic. . . . Both in industry and on the land there must be equitable taxation. ... Any belief that the economically powerful groups will do this voluntarily is illusory. They will do so only if compelled, and we alone can compel them if we intervene at all with money and technical assistance. We can 
The need for such complete participation in the economic and political life of the underdeveloped countries raises doubts that Point Four should be directed by the United States alone. Unilateral action-or more precisely, bilateral negotiation with recipient countries-is defended on the grounds that it enables the most effective use of American economic power for American political purposes. But past experience, coupled with the high degree of control required in Point Four development, tends to discredit this argument. When a lending nation seeks to direct the use of its funds, it subjects itself to the criticism that it is directing the aid in its own interests rather than in the interests of the borrowers. It assumes exclusive responsibility for the frequent decisions which affect adversely a group or a national interest. It takes the blame when aid fails to produce promiscd results. In return, it is seldom the object of national gratitute or reciprocal favor. ${ }^{19}$

International administration of the Point Four program would substitute divided responsibility for the perils of unilateral control. ${ }^{123}$ It would make the underdeveloped countries more willing to allow the administration of aid by outside personnel and more willing to compromise with outside demands. ${ }^{101}$ Direction of the program by an international authority would have the further advantage of facilitating important regional planning which could not be un-

do so by keeping our representatives on the spot, watching the exception of the program, threatening to withdraw unless the measures we demand are carried out, and withdrawing both in money and personnel, if they are not." Peffer, Point One in a Policy for Asia, N.Y. Times Magazine, May 14, 1950, p. 13, 62.

189. "Between individuals occasion is not unfrequently given for the exercise of gratitude. . . But among nations they perhaps never occur. . . [T] deduce . . a arguments for a self-denying or self-sacrificing gratitude on the part of a nation, which may have received from another good offices, is to mistepresent or misconceive what usually are, or ought to be, the springs of national conduct. ..." Hassilton, The Federalust, "The LetTERS OF PACIFICUS" No. IV, 573-575 (1818 ed.). See also Dislihe of U.S. Held Increasing Abroad, N.Y. Times, May 31, 1950, p. 1, col. 5.

190. "[S]ome parts of this development program require both a type of decision and a type of action which the people of the United States will not want their own Department of State to undertake single-handedly." ANDERson \& RAusuessusu, op. cif. supra note 184 at 30. As a matter of fact, public opinion in the United States seens favorably disposed toward international control of Point Four. See Survcy Favors Lelling the U.N. Handle Point 4, N.Y. Herald-Tribune, May 22, 1950, p. 3, col. 1.

191. International administration threatens the self-respect of recipient countries less than unilateral administration; therefore it is more likely to elicit their cooperation. See Laswell, World Polttics Faces Econoartcs 67-9 (1945). See Fox, Presidenti Truman's Fourth PoInt and the United Nations 470 (International Conciliation No. 452, 1949). "International assistance would make their dependence seem much less direct and more general. They would instead feel that they were participating in a symbolic ampaign for world reconstruction and development. Furthermore, the unpalatable truths about economic development should prove more acceptable to these countries when elaborated through an international organization of which they are a part than if handed down by. one country." Some countries actually prohibit direct investments controlled by a foreign 
dertaken by one or two nations alone. ${ }^{192}$ It would make it possible for other nations besides the United States to make contributions to the program, particularly in the fields of technical knowledge and colonial administration. ${ }^{193}$ Most important, an international authority could provide a rational means of settling economic differences arising between the mature and the underdeveloped countries, and among countries in similar stages of development. ${ }^{194}$

Present institutions for international development fall far short of this goal. Only one organization exists-the International Bank for Reconstruction and Development. ${ }^{195}$ The Bank has no jurisdiction over national development policies. It lacks the resources for a large and sustained development program. ${ }^{196}$ Its directors have consistently pursued a conservative

government. See LEwIS, op. cit. supra note 8, at 252-3. An international authority in which these countries were represented might be exempt from such legislation.

192. See Fox, op. cit. supra note 191, at 470 . The case for regional planning on the national and international level is given detailed presentation in MCDougal \& HAuER, Property, Wealth, Land: Allocation, Planning, and Development (1948). "[L]and" use problems really demand regional solutions, because of the geophysical configuration of natural areas as opposed to the artificial boundaries defining states. . . " Id. at 1070 . "Rational concern for the production and sharing of wealth and other values either in the United States or in other countries cannot today stop short with the political boundaries of the contemporary nation-state." Id. at 1166.

193. "Here is a field in which genuine international cooperation can expand and flourish. No country has a monopoly of skills, knowledge, or available personnel. Certainly the United States has no such monopoly. The amount of technical assistance will begin to approximate the need only if all nations contribute to the joint effort." Assistant Secretary of State Thorp in 20 Dep't State Bull. 287 (1949). The Western European nations aro already sharing the burden of colonial development with the United States under tho European Recovery plan. See note 3 supra and Hearings on the Point Four Bill, silpra, note 23 , at $419-21$.

194. The demands of backward nations for primary emphasis on heavy industry, sec notes 56 and 57, supra, and of colonial powers for development which dircctly aids their own economies, see note 44 supra, are not likely to yield to unilateral pressure.

195. One of the purposes of the Bank is to encourage "international investment for the development of the productive resources of members, thereby assisting in raising productivity, the standard of living and conditions of labor in their territories." Articles of Agreement, International Bank for Reconstruction and Development Art. iii (U.S. Ireasury Dep't 1944).

196. The Bank is empowered to finance development in three ways-(1) by direct loans out of its own paid-up capital and surplus (2) by floating securities on the private capital market and (3) by guaranteeing loans made by private investors. See Articles, supra noto 195 , Art. IV $\$ 1$. The total amount of loans made or guaranteed in these ways may not exceed the Bank's total capital, reserves, and surplus. Id. Art. $3 \$ 3$. According to the most recent available report, capital, reserves, and surplus totalled $\$ 1.7$ billion, exclusive of $\$ 6.7$ billion in uncalled for subscriptions. INTERNATIONAL BANK FOR RECONSTRUCTION AND Development, Fourth Annual Report 42 (1948-9). Only \$1 billion of hard-currency funds was available, however, as of March, 1949 ; of this, $\$ 650$ million was already committed. Economic \& Social Council, stipra note 5, App. I (Report of FAO) 39. 
lending policy. This is explained by the Bank's dependence on private investors for most of its capital funds. ${ }^{197}$ Bound by commercial considerations, the Bank has many of the shortcomings of private investment itself. It will not finance general programs of economic development, but only specific projects. These projects must be planned in detail; they must present the prospect of reasonable returns. When aid is granted, it is in the form of loans with customary rates of interest. The underdeveloped countries can rarely meet these terms. As a result, the very countries which need assistance the most are cut off from the only available supply of international credit. ${ }^{198}$

Point Four requires a new international institution based on fundamentally different conceptions. ${ }^{199}$ An International Development Authority

197. See note 196 supra and Econouric \& Soctal Councri supra note 5, App. I (Report of FAO) 38. This is not only a necessity, it has become a conscious policy: "In the judgment of the Bank, foreign development financing should preferably be derived mainly from private sources." IBRD REPORT, sipra note 196, at 13.

198. At the end of 1949 , only \$174 million had been loaned by the Bank to underdeveloped countries. ANDERson \& RAUSBERnBush, op. cit. sipra note 184, at 51. For a summary and defense of the Bank's present lending policies, see Ecososrrc \& Socrar Councr, stpra note 5, App. II (Memorandum Submitted by the International Banli) and IBRD REPORT, supra note 196. The Bank takes the position that "the amount of productive investment that can be undertaken in any short period of time in the underdeveloped countries will never be such as to yield rapid or spectacular results." Mremorandum, Id. at 3. Furthermore, it claims to "have or be readily able to acquire sufficient resources to finance all sound development projects in its member countries that are ready for cxeculion and that can appropriately be financed by forcign loans which are expected to be refaid." (Emphasis added). Id. at 10. For a critical view of the Bank's activities, see Ecosournc \& Soctal Councri, stpra note 5, App. IV. (Report of Subcomm. on Ec. Devel.) 15: "There are fields and types of investment required for economic development which can neither satisfy the pre-conditions required by the Bank, nor carry the interest charges involved, nor be liquidated within the period required." See also Fox, op. cit. supra note 191, at 472: "The project-by-project approach, represented by the International Bank for Reconstruction and Development ... is neither broad enough or sufficiently sustained to answer the needs of underdeveloped countries. Defense of projects in terms of their economic justification tends to ignore other projects of a 'welfare' nature which are not immediately remunerative but which must go along with the 'financially feasible' enterprises in order for the latter to succeed."

199. What follows does not purport to be anything more than a tentative proposal, illustrating the general outlines which an internationally-administered Point Four program might take. Specific proposals have already been put forward by the Public Affairs Institute. They would channel development financing through two new institutions-an International Resource Conservation Corporation and a Revolving Credit Fund for Cooperatives; and through two old ones, the International Bank and the Export ImportBank. See ANDERson \& Raushenbush, op. cit. supra, note 184, at 46 et seq.; and Anderson, A Really Bold New Program, 170 Nation 490, 491 (1950). Why four institutions must be used, two of which have serious limitations, is not entircly clear. At any rate, the philosophy behind the new institution(s) is the primary thing to agrce upon. That philosophy has been eloquently summed up by the British periodical Plamning: 
could be formed, operating within the United Nations. The Authority would have the power to finance projects which could not be financed from a country's domestic resources or from other sources under orthodox lending principles. Aid would be in the form of interest-free loans and grants. 200 It would not be confined to regions traditionally described as underdeveloped. It would be administered as far as possible without regard to political considerations. Aid would be granted wherever it was likely to produce the greatest relative increase in production and living standards. ${ }^{201}$

The magnitude of the program cannot be entirely foreseen. It would have to begin slowly, increasing with available administrative and technical facilities and with the ability of underdeveloped countries to make productive use of investment funds. Eventually, total investment by the Authority -as nearly as can be estimated from current surveys-might reach an annual figure of $\$ 6$ billion. ${ }^{202}$ The investment funds would be supplied by subscribing nations, according to their ability to contribute. The United

"The principle(s) upon which this machinery would work must differ radically from those on which international bodies have operated in the past, in two ways: First, the loans should be neither private nor simply inter-governmental but operated through an international clearing system, whose object would be equitable pooling of the burden of international investment; secondly, the criterion should not be whether a given investment is likely to prove financially profitable, but whether it provides the most economical means for relating available resources to the most urgent human needs. (Emphasis added). Quoted in BonNé, op. cit. supra note 36 at 111-12. See also Staley, World Economic DEVELOPMENT 83-91 (International Labour Office 1944).

200. It seems reasonable to agree with the International Bank that it is better to render such assistance in the form of "outright grants rather than in some form of 'fuzzy" loans which would tend to cast discredit upon the integrity of normal international investments." IBRD Report, op. cit. supra note 196, at 14. Point Four in particular requires the avoidance of "that perilous attitude, which, in reducing all major questions of international financial policy to a greedy huckster's concept of dollars and cents accounting, threatens to lose us a rational world in order to gain a few bookkecping entries of no consequence in themselves." N.Y. Herald-Tribune, Feb. 1, 1946, p. 18, col. 2 (cditorial in connection with the pending loan to Britain).

201. A proposal roughly similar to this one was presented to the United Nations during 1949. See Economic \& Soctal Council, sitpra note 5, App. IV (Report of 3d Sess. of Subcomm. on Ec. Devel.) 17-9. Although the proposal gained the support of the Subcommission of the Economic and Employment Commission, it failed to gain the approval of the Commission itself. The Commission report, however, made a gesture of compromise toward the plan by acknowledging that, in the cases of certain countrics, the U.N. should explore "various other methods" for economic development than those currently existing. Economic \& Soctal Council, supra note 5, App. V, 4.

202. Perhaps the best that can be said for estimates of this kind is that they are no more arbitrary than any other estimates. This one is based mainly on the FAO survey, supra note 196. World requirements for foreign investment (outside of North America) were approximated at $\$ 8.5$ billion a year, based on current development plans. Of this figure, $\$ 4$ billion annualiy was required by underdeveloped countries. The $\$ 5$ billion figure allows for the use of funds in some areas not strictly "underdeveloped," and for cumulative increase in the rate of development. 
States share might be about two-thirds of the total-something like $\$ 4$ billion a year. ${ }^{203}$

From present indications, such a program is certain to be attacked as too expensive for the United States. ${ }^{204}$ At its height, however, the cost to the American people would be less than two percent of their national income. In absolute magnitude, it would be considerably less than the average appropriations for foreign aid made during the first four postwar years. 05 Furthermore, by improving political and economic conditions in the backward areas, it might considerably reduce the need for emergency economic and military assistance, currently being dispensed in hasty and disorganized fashion in far-flung corners of the globe. Measured against the need for the program and the benefits it can achieve, the cost does not seem unreasonable.

American business may be expected to oppose an internationally-directed Point Four program if it appears to spell the end of private foreign investment. This result can and should be avoided. The achievements of the program in the backward areas may prove a more effective stimulant to private investment than any of the incentives currently proposed.:? Moreover, though Point Four would be planned and carried out by the experts of the various participating governments, it could also utilize the organizing ability, the technical knowledge, and the development experience of American and foreign enterprise. There would be room for those joint enterprises between private investors and governments which have enjoyed a considerable measure of success in the past. 07 The Point Four program would afford an opportunity to determine whether private enterprise and government can really cooperate for mutual benefit and a common purpose.

A final objection to such a program is likely to be levelled at the possibility

203. This is more conservative than some proposals. Sen. Brien MfcMlahon has suggested U.S. aid of $\$ 10$ billion a year for a five-year period, conditioned on Sovict acceptance of effective atomic energy control. See N.Y. Times, Feb. 3, 1950, p. 1, col. 4. Seymour Harris advocates American investment in the program of about $\$ 5$ billion annually. HaRRIS, op. cit. supra note 185, at 7,11,70. On the other hand, Morris Rosenthal has proposed American aid of $\$ 2$ billion a year over a five-year period. Rose::THAI, op. cit. supra note 8 , at 53.

204. The 81st Congress was in no mood for increased foreign spending. Even $\$ 45$ million for technical assistance was attacked as unnecessary and was eventually cut down. See notes 3 and 9 supra.

205. Government loans and grants abroad totalled \$25 billion for 1946-9. See note 8 supra.

206. By providing underdeveloped countries with foreign exchange and greater productivity, public investment could have a "pump-priming" effect on private investment. See Econoanc \& Soclal CouncIr, supra note 5, (Report of the Secretary-General) 36.

207. An outstanding example is Nelson Rockefeller's International Basic Economy Corporation. For a description of this and other experiments in "partnership capitalism," see Fortune, Feb. 1950, p. 81; Hutcheson, Gozernment and Capilal in Point Four, 25 Foreign Policy Reports 66, 69-72 (1949). 
of participation by the Soviet Union and its allies. Giving the Soviet bloc a minority influence in the administration of Point Four would certainly raise problems that the United States would not have if it retained exclusive control. But few members of the Soviet bloc still belong to the specialized agencies of the United Nations which would handle the bulk of development administration. Neither the Soviet Union nor its allies would be eligible for aid unless they allowed free access to United Nations technicians and private enterprise of foreign countries. They would also have to make available necessary economic data, as well as permit international supervision over national development projects. ${ }^{208}$ The Soviet bloc countries, if they participated at all, would have to participate on terms favorable to international political and economic cooperation.

For the time being, at least, participation by the Soviet Union itself seems unlikely. ${ }^{209}$ But several countries, not yet entirely absorbed in the Soviet sphere, would have a great interest in joining the program. Some of them still retain economic ties with the West. An international development program would offer an attractive alternative to the ruthlessly exploitative "Molotov Plan." 210 Eventually, the program might replace the present trend toward economic and political division with united activity for the general benefit. The contribution to the prestige and power of the United Nations, and to the future of world peace, would

208. These seem reasonable and necessary conditions to attach to investment under Point Four. It is interesting to note that similar provisions were included with reference to technical assistance under H.R. 7346. Assistance was to be given to countries which would (1) pay a fair share of the cost (2) provide all necessary information and give the program full publicity (3) coordinate local plans of technical cooperation (4) endeavor to make effective use of the results and (5) cooperate with other participants in the program in the exchange of technical knowledge and skills. Id. $\$ 7$ (c) Comparo these requirements with the political requirements of the Herter Bill (H.R. 6026), silpra note 11.

209. The Soviet Union however, has been the verbal champion of devclopment of the backward areas during recent U.N. meetings. See, e.g., Economic \& Sociat. Councir, supra note 5, App. V, 4. An American proposal for a large program of world development might well force the Soviets into an embarrassing dilemma. Refusal to cooperate might lose them the propaganda initiative in the backward areas; cooperation would mean raising the iron curtain and modifying their traditional pattern of autarchy. For the background of Soviet foreign economic policy, and the problems it raises for cooperation with the West, see Gardner, The Prospects for Economic Collaboration with the Soviex UNIoN (unpublished mss. in Widener Library, Harvard, and Yale Law Library, 1948).

210. Satellites whose economies still have a strongly westward orientation are Poland and Czechoslovakia. These, and other Eastern bloc countries, would find Point Four a happy contrast to the Soviet system of "putting almost nothing in and taking almost everything out" (as charged at the U.N. by Yugoslav delegate Joza Vilfan, quoted in Yakobson, supra note 16, at 136). For a summary of Russia's postwar economic activities in Eastern Europe, see $i d$. at $134-6$. 
be considerable. In days of hopelessness and despair, a boldly conceived Point Four program offers at least a chance for reuniting a divided world."21

211. The outbreak of war in Korea followed by a few days the completion of this Comment. The immediate increase in military expenditures requested by the President $-\$ 10$ billions-was more than twice the amount that has been suggested here as the annual American contribution to a comprehensive program of international development. The United States seems likely to be preoccupied for some time with military considerations. An imaginative program of economic development, however, may still represent the least expensive and most efficient way to halt the advance of Communism. The results may be slow and unspectacular, but they could some day be decisive. Secretary of State Acheson made this point in his Statement to the Senate Foreign Relations Committe, supra note 2: "The fight for freedom and democracy has been going on for more than 2,000 years. It will not ba won in a decade. The question that concerns us is whether it will be going our way ten years from now. ... [P] [art of that answer, I am convinced, lies in the energy, the slill and the faith that we put into this Point Four program." 